\title{
Adaptation of Arabic Loan Nouns in Urdu and Malay: A Comparative Study
}

\author{
${ }^{3}$ Mohana Dass Ramasamy, University of Malaya, Malaysia \\ Riaz Ahmed Mangrio, University of Gujrat, Pakistan
}

\begin{abstract}
Not all morphological adaptations between donor and recipient languages take place freely without undergoing rigorous assimilations, including phonetics/phonemics, graphemes, semantic changes, connotation changes and so on. Certain words are altered radically while some are altered moderately so that the loanwords may fit within framework of host languages. The process of adaptation as such, for sure, questions the morphological organisation of native words, while some merely challenges the grammatical organisation of the recipient. In either ways the adaptation must be concluded in the favour of recipient language rather than donor language at the end. Our investigation on adaptation of some popular Arabic Loan Nouns into two languages having two different grammatical systems, Urdu and Malay, show that both languages displayed significant degree of tolerance and the resistance against the same set of borrowed nouns. This paper lists the detailed information of the changes that allow the transformation of the borrowed terms as close as possible to host language by giving away unnecessary 'foreign' substances.
\end{abstract}

Keywords: Loanwords, Arabic Loanwords, Malay loanwords, Loanword adaptation, Noun Loans

\section{Introduction}

Previous studies related to loanword adaptations have seen growing interest of the scholars in establishing the cultural and historical contact between the donor and host languages. These studies attempted to establish the root between donor and host languages and how the latter thrived to minimise the cultural bond within new hostile environments. In the latter stage the vibration of the extended interest taken to another level to establish the root causes for apparent changes undergone by same set of lexical words in the donor and recipient languages. Though not many morphological investigations conducted within loanwords and the adaptations, growing interest still can be noticed among the phoneticians and phonologists, lately. Growing interest in studying the perception differences between the donor and host language has now enlarged the scope of scholarly debates in loanword studies to different latitude as diachronic studies. However, comparative studies investigating the adaptation nature of same set of loanwords within two different languages almost not exist in the literature of loanword adaptation.

Recent-day loanword literatures did not show promising interest on morphological changes compared to phonological changes. While some of these studies have verified the phonetics changes at large, others have focused on verifying the phonological cues, and a few have associated LWA with other aspects. Phonetically motivated speech perception theory, and phonologically motivated perception production theories account for the changes between donor and recipient languages sustained sufficient popularity among scholars. Among the two, perception theory relying on phonotactic cues remained popular and attracted interest of

\footnotetext{
${ }^{3}$ The authors' names appear in alphabetical order.
} 
many till so far. We shall see their contributions which have enriched loanword adaptation literatures before move ahead with analysis.

The proponents of speech perception principle argue that central issue of discussing loanword adaptation should focus on adaptation of foreign pronunciation into host language (Duopox and Paperkamp, 2002, 2003, Paperkamp 2002, 2003). They believe that most of the misinterpretation of loanwords in host language is due from inaccessibility to 'accurate' phonetic knowledge of source language to speakers in recipient language. A speaker, who has no access to a foreign language, may recall a loanword such as /net/ from the language as /net/ or /ned/ in a way familiar to his own linguistic capacity. The manner he interprets (misinterpretation) the term is mainly due from perceptual miscommunication but other perceptions such as phonology has no contributions at all, believe the scholars.

Proponents of production grammar believe otherwise - loan word adaptation should be addressed from the perspective of phonology. They believe that borrowed terms are nativised systematically. As a result of this the loans are adopted as close as possible to the native phonology of the recipient language, by retaining similarities as much as possible to the source languages. The non-similar foreign substances are reduced radically at various levels from segmental to prosodic (Weinreich, 1968, Hock and Joseph, 1996, Campbell, 1998). This has been attested cross-linguistically as well; Silverman (1992) for Cantonese, Ito and Mester (1995) for Japanese, Davidson and Noyer (1995) for Huave, Kentowicz (2003) for Fijian, and Kang (2003) for Korean are a few to name.

In short, these studies have demonstrated that segmental modifications precede other changes with minimal modifications or changes at the end of the borrowing process. When receiving a newer term the recipient's acceptance without alteration is limited to available phonemic similarities. Foreign elements are substituted with similar phonemes in the inventory of recipient language (Hock and Jongi, 1996). Illicit syllable forms of the foreign source also modified in language specific ways. Likewise the prosodic alterations; prosodic patterns of the source language are modified according to prosodic system of the native (Kentowicz, 2003, Broselow, 1999, 2005, Silverman, 1995).

Semantic changes have not attracted the interest of many scholars as the other field of studies. Questions of semantic assimilation were not addressed aggressively, though. Contribution of a few such as Weinrich (1953) and Bellmann (1971) are apparent during the pre-structuralist era. But the theoretical assumption of semantic changes has not achieved promising outcome as it should due to the scarcity of the literatures. The exception can be found within Bellmann's tripartite classification of semantic changes. He claims that a loanword may undergo three types of changes such as no change/ semantic change/ connotational change after the adaptation into a host language.

The present study has not been worked out on any one of these theories. This does not mean that none of them qualify for the comparative adoptability studies. Since giving the descriptive nature of phonological and morphological adaptation is the ultimate goal of this paper, we have not depended on any one of the mentioned linguistic theories in this investigation.

The present investigation on adaptation of same set of Arabic loanwords (ALW) shows that the recipient languages throw significant degree of tolerance and the resistance before 
finalising the adaptation in the favour of the latter. Tolerances and the resistances seen from different perspectives including phonetic/phonemic, grapheme, morphological, semantic, connotation in accord to grammatical system of the recipient languages is worthwhile of pursuing. The present paper investigates the adoptability patterns of same set of Arabic Nouns within two languages having different morphological and phonological requirements, Urdu and Malay. In other words, the empirical goal of the paper is investigating the characteristics of phonological and morphological adaptation of same set of Semitic loan nouns in an Indo-Aryan and Astropolynesian languages.

\section{The Data (58 words)}

The following are the list of the common Arabic loanwords that found in both languages, Urdu and Malay. The list of the ALW consists of few hundred words. Only loans that found in both languages have been chosen for present-study. Among the list the followings are lexical which are found in day-to-day communication in both languages.

\section{Arabic}

Concrete Nouns

Nouns Related to Human

Origin

Urdu Adaptation

alım (alm?) alım

askar askar

ilm/ilmi ilm

muslm

$\begin{array}{ll}\text { nazır } & \text { nazır } \\ \text { rokən } & \text { rokən } \\ \text { soltān } & \text { sultān } \\ \text { vəkil } & \text { vəkil }\end{array}$

\section{Nouns Related to Non-Human}

abjad

dunyā

hisāb

itr/utur

kitab

korsi

sharāb

abjad

dunyā

hisaāb

itr/

kitab

korsi

sharāb

Nouns Related to Place

masjd

masjid

Nouns Related to Temporal

$\begin{array}{ll}\text { al-Ahad } & \text { Ahad 'one' } \\ \text { al-khamis } & \text { Khamis } \\ \text { mawsim } & \text { monsoon } \\ \text { tarix } & \text { tarix } \\ \text { tarix } & \text { tarix }\end{array}$

Nouns Related to Action

$\begin{array}{ll}\text { Malay Adaptation } & \begin{array}{l}\text { Glossary } \\ \text { scholar/wise } \\ \text { alim }\end{array} \\ \text { askar } & \text { kny/soldier* } \\ \text { ilmu } & \text { Muslim } \\ \text { muslim } & \text { watchers/observer* } \\ \text { nazir } & \text { member/friend* } \\ \text { rakan } & \text { ruler } \\ \text { sultan } & \text { lawyer/representative* } \\ \text { wakil } & \end{array}$

abjad

letter

dunia

world

hisab

mathematic

attar

kitab

kerusi

perfume

book

chairs

sirup

alcohol drink/a drink*

masjid

mosque

Ahad

Khamis

the one/Sunday*

Thursday

monsoon season

tarikh

tawarikh history/date*

histories/history* 


$\begin{array}{llll}\text { hazIr } & \text { hazır } & \text { hadir } & \text { present } \\ \text { lazım } & \text { lazım } & \text { lazim } & \text { necessary/common* } \\ \text { qaeda } & \text { qaeda } & \text { kaedah } & \text { method } \\ \text { Qur-ban } & \text { Qurban } & \text { korban } & \text { sacrifice } \\ \text { tədbir } & \text { təd̆bir } & \text { tadbir } & \text { plan/for a thought/manage** }\end{array}$

\section{Nouns Related to Quality}

$\begin{array}{ll}\text { aqIl } & \text { aqıl } \\ \text { baqi } & \text { baqi } \\ \text { dzahıl } & \text { dzahıl } \\ \text { həq } & \text { həq } \\ \text { mahır } & \text { mahır } \\ \text { zalım } & \text { zalım }\end{array}$

$\begin{array}{ll}\text { akil } & \text { wise } \\ \text { baki } & \text { remaining } \\ \text { jahlil/jahil } & \text { ignorant/stupid* } \\ \text { hak } & \text { right } \\ \text { mahir } & \text { expertise } \\ \text { zalim } & \text { tyrant }\end{array}$

\begin{tabular}{|c|c|c|c|}
\hline \multicolumn{4}{|c|}{ Abstract Nouns } \\
\hline hadd & had & had & limit \\
\hline haram & haram & haram & forbidden thing or place \\
\hline jawāb & jawaab & jawab & answer \\
\hline maff & maaf & maaf & sorry \\
\hline mədzlis & mədzlis & majlis & assembly \\
\hline məqsəd & məqsəd & maksud & aim/meaning* \\
\hline məslək & məslək & masalah & problem \\
\hline məzhəb & məzhəb & mazhab & religion \\
\hline $\operatorname{mot}$ & $\operatorname{mot}$ & mati & death \\
\hline mufls & mufls & muflis & bankrupt \\
\hline najs & najas & najis & excrement \\
\hline qalā & alkali & alkali & saline substance \\
\hline rehmot & rehmət & rahmat & blessing \\
\hline rəqəm & rəqəm & ragam & amount/kind* \\
\hline rəsəm & rəsəm & resam & tradition \\
\hline $\int \partial \mathrm{k}$ & $\int \partial \mathrm{k}$ & syak & doubt \\
\hline shukr & shukr & syukur & thankful \\
\hline sifr & sifr & sifar & zero \\
\hline vədza(h) & vədza(h) & wadzah & reason/instrument* \\
\hline $\mathrm{s} a(\mathcal{S}) \partial \mathrm{t}$ & sa tr & saat & moment/seconds \\
\hline$\gamma \Delta \mathrm{rib}$ & gArib & karib & poor/ close \\
\hline xali & $\mathrm{k}^{\mathrm{h}}$ ali & ka:li & empty/multiply or river \\
\hline faIr & faIr & syair & poet/poem \\
\hline$x a \mathrm{~s} I j \partial t$ & xasıjat, & khasiat & quality/nutrition \\
\hline ajot & ajat & ayat & verse/sentence \\
\hline hakım & hakim & hakim & 'rulers/authorities/judge \\
\hline hokom & hokum & hukum & order/punishment \\
\hline xadım & xadrm & kadim & servant/close relative \\
\hline
\end{tabular}

* ( / ) shows the semantic difference in recipient languages in Urdu and Malay, in order.

At a first glance, it is apparent that adaptation of ALWs in the recipient languages followed the rule of thumb, replacement of phonetic/phonemic and morphological pattern with closest correspondent in the host languages. The recipient languages seemed to be modifying most of 
the illicit phonotactics of Arabic language through replacement or simplifications activities. At the prosodic level, compared to Urdu, the Malay seemed to be defusing necessary alteration to ensure the adaptation comply with its stress system as well. Before move into detailed analysis of these miniature changes transforming the loans into native intimate terms, having some background knowledge of the donor and borrower languages would be advantageous.

The paper is organized as follows. Following this introduction, the data is introduced in $\S \mathrm{x}$. $\S \S \S$ give introduction to phonetics and phonology concerned languages, Arabic, Urdu and Malay, in order. This is followed by description of phonological changes in the recipient languages, Urdu and Malay. Next to this is morphological explanation of Urdu and Malay in $\S \mathrm{x}$, and $\S \mathrm{x}$. $\S \mathrm{x}$ offers a brief sketch of semantic changes. $\S \mathrm{x}$ is the conclusion.

\section{Background of the donor borrower languages}

\section{The Arabic}

This section gives a generic overview of phonemic system of Arabic language. We have limited knowledge of the original source of Arabic loanwords from which both of these recipient languages received their contributions. It also unknown whether these languages have received the loans through speech perception or written forms from a particular Arabic dialect. Hence, to avoid confusion we have relied on source of standard Arabic phonology to illustrate the background of its phonological setting.

\section{The Phonology of Arabic}

Discussing The Grammar of Words, Booij (2009) terms the modification of base revowelling and states, "Arabic belongs to Semitic language family, and the Semitic languages are unique in their reliance on revowelling i.e. changing the form of words by replacing the vowels in them." For example, the Arabic loan noun Irada(h) 'intention' changes into an adverb Iradaton 'intentionally' by affixation though, it also requires vowel changes in the base words. As can be seen, the Arabic features of modification of base by vowel change are also found in Arabic loans in Urdu. The phonology often interrupts in the change of form both by affixation and by the modification of base. Therefore, in order to understand the affixation and the modification of base, it is also necessary to know some phonological changes in the Arabic loans. After some discussion on phonological integration of the loanwords, the derivation of words by affixation and the by the modification of base will be discussed.

Semitic language usually marked by a limited vocalic system and a rich consonantal system claims Watson (2002). So does the Arabic. The Modern Standard Arabic has 28 consonant phonemes, making phonemic contrasts between "emphatic" (pharyngealized or velarized) consonants and non-emphatic ones; Arabic is particularly rich in uvular, pharyngeal, and pharyngealized ("emphatic") sounds. The emphatic coronals $(/ \mathrm{s}^{\mathrm{s}} /, / \mathrm{d}^{\mathrm{\varsigma}} /, / \mathrm{t}^{\mathrm{\varsigma}} /$, and $/ \overbrace{}^{\mathrm{s}} /)$ cause assimilation of emphasis to adjacent non-emphatic coronal consonants.

1) i. labial consonants $(/ \mathrm{m} /, / \mathrm{b} /$ and $/ \mathrm{f} /)$

ii. plain (non-pharyngealized) coronal consonants with the exception of $/ \mathrm{r} /(/ \theta /, / \delta /$, $/ \mathrm{n} /, / \mathrm{t} /, / \mathrm{d} /, / \mathrm{s} /, / \mathrm{z} /, / \mathrm{l} /, / \mathrm{J} /$ and $/ \mathrm{d} z /)$ 
iii. pharyngeal consonants $(/ \mathrm{h} /$ and $/ \mathrm{S} /)$

iv. glottal consonants $(/ \mathrm{h} /$ and $/ \mathrm{P} /)$

v. $/ \mathrm{j} /, / \mathrm{k} /$ and $/ \mathrm{w} /$

Arabic also has three short vowels, three long vowels and two diphthongs (formed by a combination of short /a/ with the semi vowels $/ \mathrm{j} /$ and $/ \mathrm{w} /$ ). Allophony is partially conditioned by neighbouring consonants within the same word. As a general rule, e.g. /a/ and /a:/ are:

2) i. retracted to $[\mathrm{a}]$ in the environment of a neighbouring $/ \mathrm{r} /, \mathrm{x} /, / \mathrm{\gamma} /, \mathrm{q} /$ or an emphatic

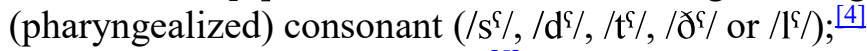

ii. [e] before a word boundary; $\frac{[5]}{[1 / 2}$

iii. advanced to [æ] in the environment of:

Arabic belongs to Semitic language family, and as Watson points out in The Phonology and Morphology of Arabic, that Semitic languages are marked by a limited vocalic system and a rich consonantal system (2002). Modern Standard Arabic has 28 consonant phonemes, making phonemic contrasts between "emphatic" (pharyngealized or velarized) consonants and non-emphatic ones; Arabic is particularly rich in uvular, pharyngeal, and pharyngealized ("emphatic") sounds. The emphatic coronals $\left(/ \mathrm{s}^{\mathrm{q}} /, / \mathrm{d}^{\mathrm{\varsigma}} /, / \mathrm{t}^{\mathrm{f}} /\right.$, and $\left./ \mathrm{\partial}^{\mathrm{\varsigma}} /\right)$ cause assimilation of emphasis to adjacent non-emphatic coronal consonants.

3) i. labial consonants $(/ \mathrm{m} /, / \mathrm{b} /$ and $/ \mathrm{f} /)$,

ii. plain (non-pharyngealized) coronal consonants with the exception of $/ \mathrm{r} /(/ \theta /, / \mathrm{d} /$, $/ \mathrm{n} /, / \mathrm{t} /, / \mathrm{d} /, / \mathrm{s} /, / \mathrm{z} /, / \mathrm{l} /, / \mathrm{J} /$ and $/ \mathrm{d} z /)$

iii. pharyngeal consonants $(/ \mathrm{h} /$ and $/ \mathrm{S} /)$

iv. glottal consonants $(/ \mathrm{h} /$ and $/ \mathrm{R} /)$

$/ \mathrm{j} /, / \mathrm{k} /$ and $/ \mathrm{w} /$

Arabic consonants are divided into two groups. They are called the sun letters and moon letters based on whether or not they assimilate with the $/ \boldsymbol{l} /$ of the definite article $a l / \boldsymbol{c} l$. The sun letters are $\mid \mathrm{t} /, / \theta /, / \mathrm{d} /, / \mathrm{d} /, / \mathrm{r} /, / \mathrm{z} /, / \mathrm{s} /, / \mathrm{J} /, / \grave{\mathrm{s}} /, / \mathrm{d} /, / \grave{\mathrm{t}} /, / \grave{\mathrm{d}} /, / \mathrm{l} /$ and $/ \mathrm{n} /$, while the moon letters are $|b /,| \check{g} /,|h|,|h|,|\dot{g} /| f,|| q,|| k,||, m /,|w|,|y|,|h|$.

Arabic also has three short vowels, three long vowels and two diphthongs (formed by a combination of short $/ \mathrm{a} /$ with the semi vowels $/ \mathrm{j} /$ and $/ \mathrm{w} /$ ). Allophony is partially conditioned by neighbouring consonants within the same word. As a general rule, e.g. /a/ and /a:/ are:

4) i. retracted to $[\mathrm{a}]$ in the environment of a neighbouring $/ \mathrm{r} /, / \mathrm{x} /, / \mathrm{\gamma} /, \mathrm{q} /$ or an emphatic (pharyngealized) consonant $\left(/ \mathrm{s}^{\mathrm{\varsigma}} /, / \mathrm{d}^{\mathrm{\varsigma}} /, \mathrm{t}^{\mathrm{\varsigma}} /, / \mathrm{ठ}^{\mathrm{\varsigma}} /\right.$ or $\left./ \mathrm{l}^{\mathrm{\varsigma}}\right) ;$; $^{[4]}$

ii. [e] before a word boundary; ${ }^{[5]}$

iii. advanced to $[æ]$ in the environment

Next we will the phonetics and phonology of the recipient languages in brief. 


\section{The Urdu}

\section{Phonetics and Phonology of Urdu}

Urdu belongs to the family of New Indo-Aryan (NIA) languages, which is a sub branch of the Indo-European languages (Hussain, 1997, p. 39). It is mainly influenced by Arabic and then Persian and English. Abdul Haq, father of Urdu, disagrees with the Urdu grammarians who follow Arabic rules. As, on one hand, Urdu is a language of Indo-Aryan family, and Arabic, on the other hand, is from Semitic family. There is not yet an agreed phonological inventory in Urdu, and one of the core reasons of no scientific speech processing research is the absence of an agreed phonological inventory of Urdu sound system. The pronunciation of Urdu varies from region to region. This is also the main reason behind no consensus on the number of oral vowels and consonants in Urdu. Some researchers i.e. Katchru, (1990), Hussain (1997), Bokhari $(1985 ;$ 1991) and Khan (1997) have described from 10 to 17 vowels including nasal vowels, but there are a lot of controversies. They have agreed on 10 vowels. It's been problematic for the researchers in Urdu phonology. The majority of the world languages do not use diphthongs in their phonological inventory (Laver, 1994). Clark and Yallop (1995) say, though, if there are more than ten vowel sounds in a language, then it may be exploiting diphthongs combinations. On the contrary, (in the case of Urdu), Bokhari (1991) and Alam (1997) and others agree on more than 10 vowels in Urdu, but they stress that no diphthongs phonemically exist in Urdu. Isn't it contrasting argument that Urdu has more than ten vowels and, and has no diphthongs? There are certain cases in which we can find diphthongs e.g. kpi 'anybody', dzan 'go' and gav 'sing'. Waqar \& Waqar (2002) find in their survey and agree to an extent that phonemically diphthongs do not exist, but phonetically there are 13 diphthongs in Urdu. In all the cases they are formed from the deletion of the consonants: $/ \mathrm{P} /, / \mathrm{j} /$ and,$/ \mathrm{v} /$. Deletion of a sound in any word causes vowel lengthening such as darxvast 'request' and barxvast 'suspend' the consonant $/ \mathrm{v} /$ is deleted and the words are actually spoken with long vowels as drrxast and brxxast. Following is the Urdu vowel chart taken from Ohala (1999). Urdu vowels found in the initial, medial, and final positions.

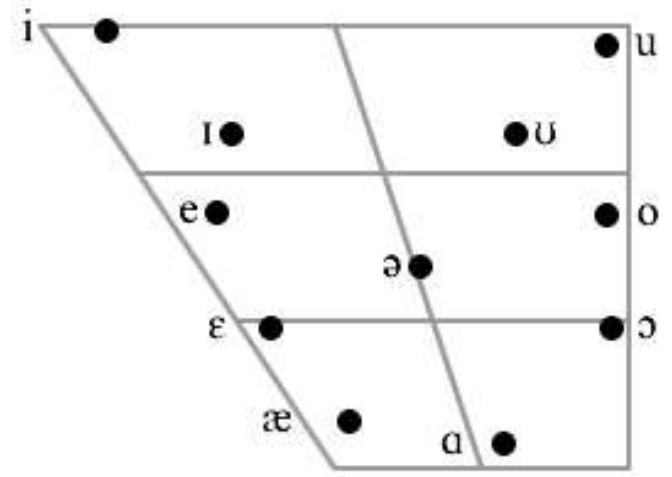

(Ohala,1999)

\section{Consonants}

There has been no agreement on the number of consonants, as well, in Urdu. Some researchers i.e. Kachru, (1990), Hussain (1997), Bokhari (1985; 1991) and Khan (1997) have described from 36 to 44 consonants, but they have agreed on 28 consonants. Supplementing these are 2 consonants that are internal developments in specific word-medial contexts (Shapiro, 2003), and 7 consonants originally found in loan words. Loanwords from Arabic 
via Persian introduced five consonants, /f, z, q, $\mathrm{x}, \mathrm{\gamma} /$. The sibilant $/ \mathrm{f} /$ is found in loanwords from all sources (English, Persian, and Sanskrit) and is well-established (Ohala, 1999). Most native consonants may occur geminated (doubled) which are always medial and preceded by one of the interior vowels $(/ \mathrm{a} /, / \mathrm{I} /$, or $/ \mho /)$. Hindi/Urdu draws it's higher, learned termsEnglish, Sanskrit, Arabic, and to a lesser extent Persian provide loanwords with a rich array of consonant clusters. The introduction of these clusters into the language in fact contravenes an historical tendency within its native core vocabulary to eliminate clusters through processes such as cluster reduction and epenthesis (Shapiro, 2003). In the IPA, the five murmured consonants can also be transcribed as $/ \mathrm{b} /, / \mathrm{d} /, / \ddot{\mathrm{d}} /, / \mathrm{d} \ddot{z} /$ and $/ \ddot{\mathrm{g}} /$ respectively. Shapiro (2003:260) notes that the series of so-called voice aspirates should now properly be considered to involve the voicing mechanism of murmur, in which the air flow passes through an aperture between the arytenoids cartilages, as opposed to passing between the ligamental vocal bands."

\begin{tabular}{|c|c|c|c|c|c|c|c|c|c|c|c|c|c|}
\hline & \multicolumn{2}{|c|}{ Bilabial } & $\frac{\text { Labio- }}{\text { dental }}$ & \multicolumn{2}{|c|}{ 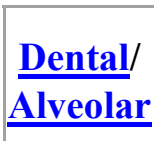 } & \multicolumn{2}{|c|}{ Retroflex } & \multicolumn{2}{|c|}{$\frac{\text { Post- }}{\text { alv./ }}$} & \multicolumn{2}{|c|}{$\underline{\text { Velar }}$} & $\underline{\text { Uvular }}$ & Glottal \\
\hline Nasal & \multicolumn{2}{|c|}{$\mathrm{m}$} & & \multicolumn{2}{|c|}{$\mathrm{n}$} & \multicolumn{2}{|c|}{ (n) } & & & & & & \\
\hline$\underline{\text { Plosive }}$ & \begin{tabular}{|l|}
$\mathrm{p}$ \\
$\mathrm{p}^{\mathrm{h}}$
\end{tabular} & $\begin{array}{c}\mathrm{b} \\
\mathrm{b}^{\mathrm{fi}}\end{array}$ & & \begin{tabular}{|c|}
$t$ \\
th \\
th \\
\end{tabular} & $\begin{array}{l}\mathrm{d} \\
\mathrm{d}^{\mathrm{f}}\end{array}$ & $t^{\mathrm{h}}$ & $\begin{array}{l}\mathrm{d} \\
\mathrm{d}^{\mathrm{fi}}\end{array}$ & & & \begin{tabular}{|c|}
$\mathrm{k}$ \\
$\mathrm{k}^{\mathrm{h}}$ \\
\end{tabular} & $\begin{array}{c}g \\
g^{\mathrm{h}}\end{array}$ & (q) & \\
\hline Affricate & & & & & & & & & & & & & \\
\hline Fricative & & & $\mathrm{f}$ & S & z & & & $\int$ & & (x) & & & h \\
\hline$\underline{\text { Tap or Flap }}$ & & & & & f & & c) & & & & & & \\
\hline Approximant & & & v & & 1 & & & $\mathrm{~J}$ & ] & & & & \\
\hline
\end{tabular}

Table: Consonants of Hindi and Urdu. Marginal and non-universal phonemes are in parentheses.

\section{Syllabification}

Syllabification is an essential concept to understand phonological structure (Kenstowicz, 1994). It helps us understand phonological properties. Ladfoged (1993) defines syllable as the smallest possible unit of speech sound. There are three elements in its structure i.e. onset, nucleus and coda. Nucleus and coda are connected with a node-rhyme.

Bokhari (1985) and Hussain (1997) agree that more work is needed on Urdu syllables. Ghazali (2003: 4) has identified eleven syllables e.g. CV, CVC, CVCC, CVV, CVVC, CVVCC, V, VC, VCC, VV AND VVC. He describes that basically there are six syllable templates and the other five are actually derived from these fundamental templates. I have 
observed that he has missed one and there are in fact twelve syllable templates in Urdu. He hasn't mentioned the twelfth one i.e. CCVCC.

\begin{tabular}{|c|c|c|}
\hline Syllable Template & Example & Meaning \\
\hline $1-\mathrm{CV}$ & hæ & is \\
\hline 2-CVC & kpn & who \\
\hline 3-CVCC & dpst & friend \\
\hline $4-\mathrm{CVV}$ & $\mathrm{d} z a \mathrm{p}$ & go \\
\hline 5-CVVC & saət & moment \\
\hline 6-CVVCC & saaxt & structure painda(h) \\
\hline $7-\mathrm{V}$ & $a$ & come (informal) \\
\hline $8-\mathrm{VC}$ & an & honour \\
\hline $9-\mathrm{VCC}$ & $\mathrm{Ilm}$ & knowledge \\
\hline $10-\mathrm{VV}$ & $a \mathfrak{D}$ & come (little formal/plural) \\
\hline $11-V V C$ & ain & constitution \\
\hline 12-CCVCC & drəxt & tree \\
\hline
\end{tabular}

Nonetheless, looking at all, we come to know that Urdu has a variety of syllables-both light and heavy. They contain maximum of two consonants in a sequence. There are complex codas and complex onsets, as well, the last example above, which Ghazali hasn't mentioned. Such as the words like draxt 'tree' give the clear evidence to us. So the total number of possible Urdu Syllable structures is twelve not eleven. Though there are certain restrictions regarding the position and the classes of consonants, we will mention just one here. Hussain (1997) points out that when there are two coda consonants, the first is limited to voiceless fricative $/ \mathrm{f} /, / \mathrm{s} /, / \mathrm{x} /, / \mathrm{J} /$ or nasals $/ \mathrm{n} /, / \mathrm{m} /$ and the second consonant is limited to stops e.g. saxt 'hard', kazb 'lie' and $I r \partial f t$ ' 'control'. Open syllables are considered more frequent than closed syllables. Ghazali (2003: 6) describes the presence of glottal stop (which is controversial however) in the onset-less syllables e.g. am 'common'. Like other subcontinent languages, Urdu also has the possibility of re-syllabification i.e. a change in the syllable boundary that is caused by the addition or deletion of an affix in it. For example, in the words $d z a n$ 'beloved' vs $d z a . n u$ 'beloved', the syllable changes its boundary from [n.] to [a.], and there is no effect on the meaning.

\section{Phonetics and Phonology of Malay}

In what follows given are some background information of phonetics and phonology of Malay to assist the forthcoming investigations. Phonetic inventory of the Malay is simple and straightforward. Malay has a simple vowel system with eight surface vowels which are represented by five vowels (a,e,i,o,u), and 28 consonants (Hassan, 2005) represented by 21 consonants orthographically. The charts in $(\mathrm{x})$ and $(\mathrm{x})$ represent the underlying and surface phonemes in Malay, which will be referred from time to time in this study.

\section{Malay Vowels}

$\begin{array}{llll} & \text { Front } & \text { Middle } & \text { Back } \\ \text { Narrow } & \text { i } & & \mathrm{u} \\ \text { Half-Narrow } & \mathrm{e} & & \mathrm{o}\end{array}$


Half-open

Open

(Hassan, 2005: p56)

\section{Malay Consonants}

$\begin{array}{lllllll} & \text { Labial } & \text { Dental } & \text { Alveolar } & \text { Palatal } & \text { Velar } & \text { Glottal } \\ \text { Plosives } & \mathrm{p}, \mathrm{b} & \mathrm{t}, \mathrm{d} & & & \mathrm{k}, \mathrm{g} & \text { ? } \\ \text { Affricatives } & & \mathrm{n} & & \mathrm{c}, \mathrm{j} & & \\ \text { Nasals } & \mathrm{m} & \mathrm{n} & \mathrm{n} & \mathrm{y} & \\ \text { Fricatives } & \mathrm{f}, \mathrm{v} & \theta, \mathrm{d} & \mathrm{s}, \mathrm{z} & \mathrm{s}, \mathrm{z} & \mathrm{x}, \mathrm{\gamma} & \mathrm{h} \\ \text { Trill } & & \mathrm{r} & & & & \\ \text { Liquids } & & \mathrm{l} & & & & \\ \text { Glides } & \mathrm{w} & & \mathrm{y} & & & \end{array}$

(Hassan, 2005: p57)

It is apparent from the chart that Malay has a simple set of phonemic inventory. Malay vowel system is represented by a simple set of phonemes. Besides the five true vowels such as /a,e,i,o,u/, the language is believed to have three allophones with wide-spread applications, namely, the half-open Front, / $/ \varepsilon /$, Mid, /a/ and Back, / / / segments. Vowel length is a contractive phenomenon, which is conditioned by place of occurrences in this language. For instance, the vowel of the initial syllable $/ \mathrm{ka} / \mathrm{in} / \mathrm{kata} /$ 'say', is shortened, while the vowel in the open-ended final syllable /ta/ is lengthened. Vowel shortening and vowel lengthening are not distinctive features of the language; hence, they have not been presented orthographically.

According to Abdullah, Malay has 28 surface consonants. All of these consonants are represented by 21 consonants in the orthographic system of the language. The chart of surface consonants is straightforward. Most of the consonants have independent place, except for the three Fricatives - dental, palatal and velar fricatives. The $/ \theta /$ and $/ \delta /$ are allophones of the $/ \mathrm{t} /$ and $/ \mathrm{d} /$, respectively, while the retroflex fricatives $/ \mathrm{s} /$ and $/ \mathrm{z} /$ are treated as allophones of $/ \mathrm{s} /$ and $/ \mathrm{z} /$. The velar-fricative $/ \mathrm{\gamma} /$ is alternate of $/ \mathrm{x} /$, and the allophonic realization is defined by surrounding sound segments. It must be stressed that the chart shows that Malay is lack of Laryngeal and Pharyngeal sounds which are common in Arabic.

Basic syllable structure of Malay is (C) V (C) (Abdullah, 1974, Yunus 1980, Farid, 1980, Zaharani 2004). The language allows a single segment to occupy any one of the syllable constituent. Neither onset-cluster nor coda-cluster is allowed in native Malay, therefore. However, there are further restriction applied towards individual segments from occupying the coda positions, but onset positions are free from such restrictions. Nucleus are designated for vowel segments, therefore the language has no non-vocalic nuclei.

Clustered consonants $\left({ }^{*} \mathrm{CC}\right)$ are totally prohibited phenomenon in native Malay vocabulary. Neither of Onset-clusters or Coda clusters is permitted in the native words of Malay. However, the flexibility is not extended to present-day loan words. Following the modernization effort triggered by Dewan Bahasa dan Pustaka, English loan word adaptations allowed the language to accommodate some forbidden restrictions, and surface with onset- 
clusters, such as in /klik/ 'click', /klinik/ 'clinic', /premis/ 'premise' and so on. Except for some of those present-day loan word adaptations, especially those from English, other assimilated loan words abide the native syllabification system.

With these basic phonetic and phonotactics knowledge let us see the data and the adaptation flexibility enforced by these languages.

\section{The Phonology}

\section{Phonology of Arabic Loanwords in Urdu}

Urdu has almost all the 'sounds' available in any other language spoken in the world (BBC, 2010). Certainly, most of these sounds are loans and many among them are Arabic. From a large number of Arabic loans, many of the consonant sounds have completely changed. In his introductory Urdu, Naim (1999) notes that most Arabic loans in Urdu "can be easily recognised, because they contain dentals and the emphatic dentals i.e. ث/t/, b/t/t, ح/h/, ذ/ð்/,

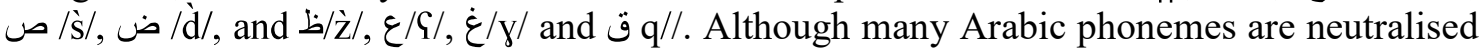
in Urdu, all Arabic loanwords can however be recognised. The recognition of Arabic loans is due to the fact that Urdu is written in Arabic script and a large number of Arabic loans in Urdu are also read in the Quran. This means that if one finds a word in Urdu that he/she recognises from the Quran, it must be from Arabic, and therefore a loan. However, there is in fact no difference left in the Arabic dentals and emphatic dentals in Urdu. For example,

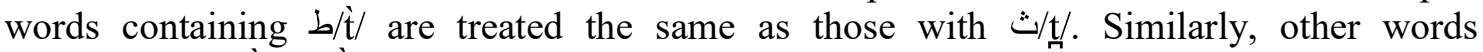

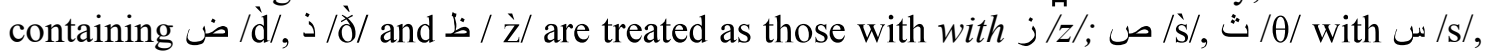
$\tau / \hbar /$ with $\bullet / h /$ and $\varepsilon / \mathcal{S} /$ with a vowel. Interestingly, children learning the Quran, at different Islamic institutions, are given special training and practice to pronounce the words correctly, but in speaking Urdu, they ignore the Arabic pronunciation of the same words. Below is the brief sketch of integration of Arabic loans due to the changes in the Arabic loanword phonology.

\section{Phonological Integration of Arabic Loans: Consonantal Integration}

Making computational analysis of morpho-syntactic categories in Urdu, Hardie (20003) observes that its consonant inventory is somewhat different from that of Arabic. Distinctions that existed in Arabic are neutralised in Arabic loans in Urdu, which accommodates Arabic phonemes in its sound system. There are many similar sound segments of the vowels and the consonants, between native and loans that do not show changes and are adopted without any modification. However, those only borrowed from Arabic are modified significantly. The loanwords undergo important alternations of the vowel and consonant segments, and the foreign sounds segments are replaced showing more 'native essences'. Note the difference between the Arabic dentals and emphatic dentals in Urdu. As said above, words containing

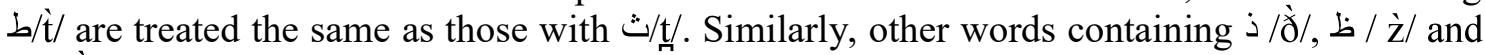

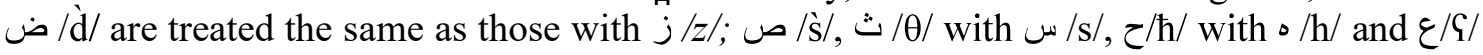
with a vowel.

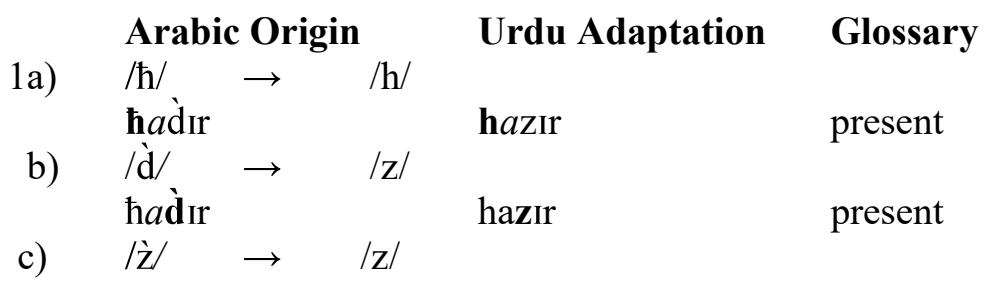




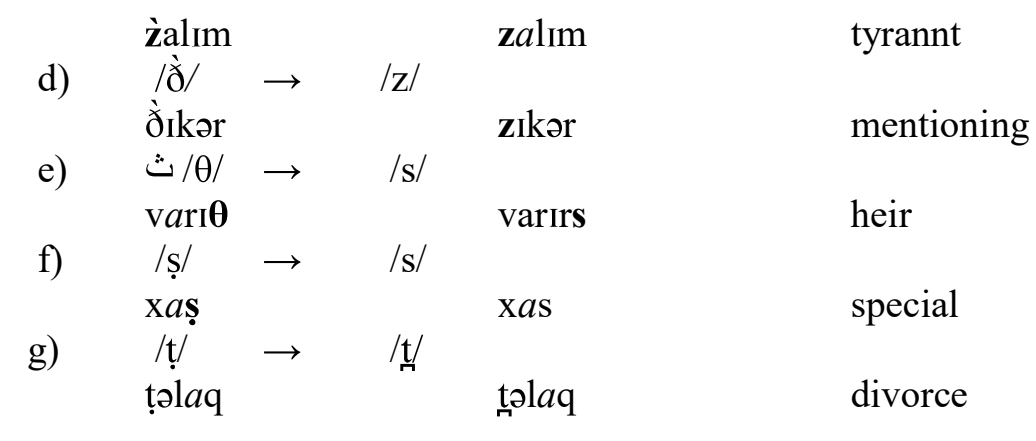

h) $\quad / \mathrm{S} / \rightarrow$ following vowel

$\begin{array}{lll}\text { YIlm } & \text { Ilm } & \text { knowledge } \\ \text { fac } a l & \text { f } a^{\prime} \boldsymbol{a l} & \text { active }\end{array}$

Note in (1a) that Arabic voiceless pharyngeal fricative $/ \hbar /$ is pronounced as simply aspiration $/ h /$ in Urdu. Therefore, there is no phonological difference between $/ h /$ and $\hbar$ in the Arabic loans like hadi 'leader/guide' and hadz̧i 'pilgrim'. Both the words begin with $/ h /$. Similarly, note in (1b) that the Arabic dental / $d /$ is also neutralised and substituted by the alveolar voiced fricative $|z|$. Due to the nuetralisation of these sounds, the words like $\boldsymbol{\hbar} a \dot{d} I r$ 'present' are pronounced as hazIr. The alveolar voiced fricative $|z|$ substitutes two more Arabic phonemes i.e. dental voiced fricative $/ \grave{\delta} /$ and voiced strident fricative $/ \grave{z} /$ in the loanwords żalım 'tyrant' (1c) and ð̀.kər 'mentioning' (1d). When pronounced with alveolar voiced fricative $\mid z /$, the two words are zalım and zıkar. This is also necessary to say that there is no difference of the position of these sounds to occur in the words whether initially, medially or finally. They contain no difference and are neutral in Urdu.

Some other Arabic sounds neutralised in Urdu are i.e. voiceless dental fricative $\mid \theta /$, and the emphatic sounds $/ s /$ and $/ t /$. However, the substitution is made by two separate native phonemes. For example, voiceless dental fricative $/ \theta /$ as in $\operatorname{var} \theta \theta$ 'heir' (1e) is replaced by voiceless alveolar fricative $/ s /$, which also substitutes the emphatic sound $/ s /$, as seen in $x a s$ 'special' (1f). Therefore, the words are pronounced in Urdu as varis and xas. The last emphatic sound $/ t /$ as in tolaq 'divorce' ( $1 \mathrm{~g}$ ) is also neutralised and changed with voiceless dental stop $/ t /$. The word is now spoken as tolaq. Finally the pharyngeal fricative $/ \mathrm{G} /(1 \mathrm{~h})$ is deleted and the word is pronounced with the following vowel.

The Arabic consonant considered alien to Urdu phonology i.e. voiced pharyngeal fricative / $/$ / is the subject of controversy. There is no agreement on its existence. Hardie (2003) refers Bhatia and Koul (2000) that it is pronounced as a glottal stop, as zero, as $\bar{a}$ or as $a$, depending on a range of factors including its environment. He states that it is not found in Urdu, and so its pronunciation is unpredictable. However, the Urdu pronunciation of Arabic loans gives the evidence that voiced pharyngeal fricative $/ \mathcal{S} /$ is in fact deleted. Arabic loans e.g. Salim 'scholar' and Somer 'age' are pronounced with the following vowels $/ a /, / \mathrm{p} /, / \mathrm{I} /, / \mathrm{a} /$ and $/ \mho /$, instead. Even the presence of glottal stop, which replaces pharyngeal fricative $/ \mathcal{S} /$ according to Bhatia and Koul, is also an issue of argument. Some writers e.g. Hussain and Afzal (2001) and Shahid (2002) agree that it is controversial. Shahid (2002) comes to the conclusion that no rule completely describes the existence or removal of glottal stop, while Hussain admits that the existence is a controversial matter and a point of open debate ${ }^{4}$.

\footnotetext{
${ }^{4}$ Email correspondence with him (November, 2007)
} 
Some loan Arabic phonemes i.e. $/ q /, \mid x /$ and $/ \gamma /$ are part of Urdu inventory, but they are frequently confused with some native phonemes i.e. $/ \mathrm{k} /, / \mathrm{k}^{h /}$ and $/ g /$ respectively, particularly in some areas where Urdu is not the first language. This is discussed below separately.

\section{Consonantal Integration: The Confusion: $q / k /, x / k^{\mathrm{h}}$ and $\gamma / g$}

Generally, following some adaptation rules like other recipient languages, Urdu tends to accommodate loan words. However, the pronunciation of Urdu varies from region to region, which affects the loanword phonology also. Some consonantal segments adopted in most regions, e.g. Hyderabad, Karachi, Lahore and Lukhnow, are replaced with other consonants in some other areas. In this regard, uvular stop /q/ vs voiceless velar stop /k/, voiceless velar fricative $/ \mathrm{x} /$ vs aspirated voiceless velar stop $/ \mathrm{k}^{\mathrm{h}} /$ and voiced velar fricative $/ \gamma /$ vs voiced velar stop /g/ are important to discuss. For example, many people find it hard to pronounce $/ \mathrm{q} /$ and do not distinguish/q/ and $/ \mathrm{k} /$. Note the followings:

2) $\quad / \mathrm{q} / \rightarrow / \mathrm{k} /$

$\begin{array}{llll} & \text { Arabic Origin } & \text { Urdu Adaptation } & \text { Glossary } \\ \text { i) } & \mathbf{q} a \text { tıl } & \text { k } a \text { țl } & \text { 'kill' } \\ \text { ii) } & \text { qISəm } & \text { kISəm } & \text { 'type/kind' } \\ \text { iii) } & \text { qIla } & \text { kIla } & \text { fort }\end{array}$

People other than the areas mentioned are still confused with uvular/q/ stop and velar stop /k/. The famous Urdu poet Shabir Hasssan Josh was much concerned about the uvular stop /q/, and was often angry for not pronouncing it correctly (Rehman, 2003). Similar to this is the confusion of $/ \mathrm{x} / \mathrm{vs} / \mathrm{k}^{\mathrm{h}} /$ and there is no difference left, as shown below:

3) $\quad / \mathrm{x} / \rightarrow / \mathrm{kh} /$

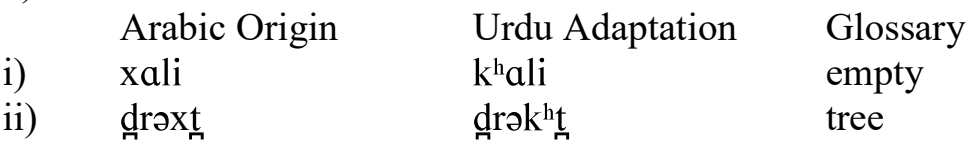

As Hindi lexicon lacks these phonemes, perhaps this is why mostly Indians, and many Pakistanis are confused in the use of voiceless velar fricative / $\mathrm{x} / \mathrm{vs}$ aspirated voiceless velar stop $/ \mathrm{k}^{\mathrm{h}} /$. I have noticed this confusion even in my family members. They cannot differentiate between the words like $\boldsymbol{x o l}$ 'case/sheath' and $\boldsymbol{k}^{h} O l$ 'open'. Both are spoken as $\boldsymbol{k}^{h} O$ l. This is mainly due to the influence of Indian movies, which are equally popular in both Pakistan and India. This influence has also affected the mix up of another Arabic phoneme i.e. voiced velar fricative $/ \gamma /$ with voiced velar stop $/ \mathrm{g} /$.

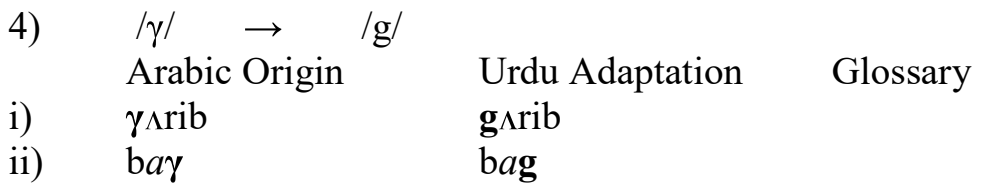

This mix up of the two sounds is a good evidence of the phonological integration of the Arabic loanwords. Note that there is no differentiation left between the two sounds in $\boldsymbol{\gamma}$ arib/ g^rib. The word is actually pronounced as g^rib. The words like this, and some others 
discussed, show the confusion of the sounds in some regional dialects of Urdu. This is, however, not the dominant feature in the standard language. Arabic phonemes are important properties of Urdu, and distinctive from Hindi phonemes used in the same words in both the languages. Further, it is interesting to note that the two phonemes $/ \gamma /$ and $/ \mathrm{x} /$ have in fact substituted some phonemes even in the native words. This is a unique aspect of loanword integration and need to be discussed separately.

\section{The Substitution of Native Phonemes by Arabic Phonemes in Native Words}

One of the most interesting feature of Arabic loan integration is that some Arabic phonemes i.e. voiceless velar fricative $/ \mathrm{x} /$ and voiced velar fricative $/ \mathrm{y} /$, rather than loanwords or affixes, have entered native words, though the number of such words is not enormous. By native words, it is meant to say that they may have been derived from within Urdu, Sanskrit, Hindi or any other local languages. Consider first some examples with voiceless velar stop $/ \mathrm{x} /$ :

\begin{tabular}{|c|c|}
\hline Word Origin & \\
\hline 5a. Jəlaka & (Sanskrit) \\
\hline b. tinkrəka(h & 1) (Sanskrit) \\
\hline c. $\int a k^{h}$ & (Sanskrit) \\
\hline $\begin{array}{l}\text { d. -- } \\
\text { e. torka }\end{array}$ & $\begin{array}{l}-- \\
\text { (Hindi) }\end{array}$ \\
\hline f. tItkari & (Hindi ) \\
\hline g. pətax $a$ & (Urdu) \\
\hline 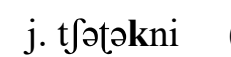 & (Hindi) \\
\hline 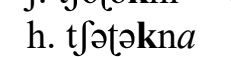 & (Hindi) \\
\hline i. pətəkna & (Hindi) \\
\hline
\end{tabular}

(entered through) Use in Urdu

səlax 'rod / iron bar' $(\mathrm{N})$

təxna 'ankle' $(\mathrm{N})$

fax 'branch' (N)

$\int a x($ Persian $)$

bə⿳亠丷厂彡k (Persian)

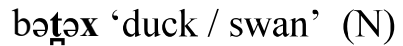

orxana 'to reject (a request) humbly' (V)

tItxari 'clacking of tongue to run a

horse/donkey'

pataxa 'cracker'/ '(slang) beautiful or

sharp girl' (N)

t $\int \partial t \partial x n i$ 'a bolt to lock to the door' $(\mathrm{N})$

t $\int \partial t \partial x n a$ 'to crackle' (V)

pətəxn $a$ 'to throw down violently' (V)

Note that most words have been derived from Sanskrit, some from Hindi and some created within Urdu. With or without the alternations of the sounds, a few words have also entered Urdu via Persian i.e. Sanskrit $\rightarrow$ Persian $\rightarrow$ Urdu. This is an interesting phenomenon, as Sanskrit words (considered native in this work) entered Urdu either directly or via Hindi. It is also interesting to note that it does not affect the substitution process whether any word entered Urdu via Persian e.g. $\int a x(5 c)$ or directly e.g. salax (5a). The one in (5c) may be claimed to be a simple loan from Persian, but the other in (5a) gives the concrete evidence that there is a substitution of native phoneme $/ \mathrm{k} /$ by loan phoneme $/ x /$ in the native words. Almost all examples show that voiceless velar stop $/ \mathrm{k} /$ is substituted by voiceless velar fricative $/ \mathrm{x} /$. Some words contain aspirated velar stop $/ k^{h} /$ e.g. $\int a k^{h}(5 \mathrm{c})$ in their origin. But the changes remain on the same pattern i.e. $/ \mathrm{k} /$ or $/ k^{h} /|x|$ as in fax 'branch'. Besides the substitution of native sound by the loan sound, there are some alternations of vowels in the same words, but this is not seen in large majority. As can be seen, some contain a word final vowel /a/ e.g. Solaka (5a). It can be assumed that it was first deleted at some stage of the language growth. Then the two consonants i.e. postalveolar fricative $/ \mathrm{J} /$ and voiceless velar stop $/ \mathrm{k} /$ were substituted by alveolar fricative $/ \mathrm{s} /$ and voiceless velar fricative $/ \mathrm{x} /$ respectively. The rigorous alternation of vowels is however not necessarily seen in other examples.

In all native words, the loan phoneme velar fricative $/ \mathrm{x} /$ appears generally in the word final position. Most words containing this in the word medial position e.g. saxt 'structure' are loans from Persian. Many others showing /x/ word initially e.g. xatra 'danger' are Arabic 
loanwords. The words having / $\mathrm{x} /$ in the initial and medial position are however simple loans, and there is no transformation of sounds except in a few examples e.g. bə⿳亠丷厂犬火 $\rightarrow$ bətəx 'duck / swan' in (5d). Note first that the word is a loan from Persian but is modified by Arabic sound. Besides, in the same word, there are two contrasting features. The loan Arabic phoneme i.e. emphatic dental $/ \mathfrak{t} /$ is substituted by the native Urdu dental $/ \mathrm{t} /$ word medially. At the same time, there is a quite opposite process. The velar stop $/ \mathrm{k} /$, though the native Urdu sound also, is substituted by velar fricative $/ \mathrm{x} /$ that is in fact a loan phoneme.

An interesting aspect of this sort of integration is to see that two contrasting sounds, one a native i.e. voiceless retroflex stop $/ t /$ and the other a loan i.e. voiceless velar fricative $/ \mathrm{x} /$ get together and transform or produce a word in Urdu e.g. pətaxa 'cracker'. The native-loan phoneme combination is not restricted to $/ \mathrm{x} /$ (Arabic loan) and / $/$ / (native Urdu). There is another correlation i.e. voiced retroflex stop $/ d /$ (native) and voiced velar fricative $/ \gamma /$ (loan). Thus there are two pairs of native retroflex stops $/ \mathrm{t} /$ and $/ \mathrm{d} /$ and two loan velar fricatives $/ \mathrm{x} /$ and $/ \mathrm{y} /$. There can be a native-loan combination of any sounds from the two pairs. Although there are not many examples, some as given below also show this.

\section{Word Origin}

$\begin{array}{ll}\begin{array}{ll}\text { 6. yond } a \\ \text { b. yət yət }\end{array} & \text { (Sanskrit) } \\ \text { c. yorrahət } & \text { (Urdu) } \\ \text { d. yərəp } & \text { (Urdu) }\end{array}$

\section{via (entered through)}

-

\section{Use in Urdu}

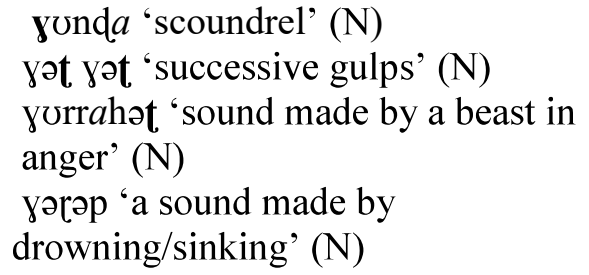

Note that the native-loan phoneme correlation makes either a phonetic transformation of a native word e.g. yonda 'scoundrel' or even produces a new word e.g. yət yət 'successive gulps'. The combination of voiced or voiceless retroflex stops / $d /$ and $/ \mathrm{t} /$ with velar fricative $/ \mathrm{y} /$ is even less frequent, and that of $/ \mathrm{x} /$ and $/ \mathrm{d} /$ is almost none. However, there may be rare examples of loan fricatives $/ \mathrm{\gamma} /$ or $/ \mathrm{x} /$ with the native flap sound $/ \mathrm{r} / \mathrm{e} . \mathrm{g}$. zərəp 'a sound made by drowning/sinking'.

Note also that whether it is the formation of new words or the transformation of the old words from Hindi and Sanskrit, most derived words are nouns and some are verbs. The verbs are from the infinitive class. The majority of words shows that the most are either names of different sounds e.g. $y \partial t$ yət 'successive gulps' or the things producing these sounds e.g. prtaxa 'cracker'. The substitution of native phoneme by loan phoneme e.g. velar stop $/ \mathrm{k} / \rightarrow$ $/ \mathrm{x} /$ is quite a reverse process from the one seen in regional dialects of Urdu as noted above.

Talking on Hindi in Indo-Aryan Languages, Shapiro (2003), terms the presence of loan phoneme in native words as hypercorrect pronunciations. He does not nonetheless discuss in detail, and just notes that in some instances they "are heard in which Hindi words are pronounced with loan phonemes, as though the items were foreign borrowings e.g. $f \mathrm{ir}$ 'then' instead of phir." The Urdu perspective in this regard is little different from that of Hindi. The two phonemes $/ \mathrm{x} /$ and $/ \mathrm{y} /$, though loans from Arabic, are however part of Urdu phonetic inventory now. They are no more seen in only Arabic loans. Along with the combination of native Urdu phonemes, they have rather started producing new words. Therefore, their function in native words is the same as that of the native phonemes. This cannot be merely called hypercorrect pronunciation. This is a higher function, and should be considered as renovation of Urdu lexicon, which includes some words produced by these phonemes. The native word formation by the two Arabic loan fricatives is a distinctive process. Urdu has 
borrowed a variety of processes, from Arabic, similar to this, showing some word formations. One of them is assimilation.

\section{Assimilation}

The assimilation in Arabic loan is between the two nasals i.e. voiced and voiceless alveolar nasal stop when followed by voiced bilabial stop i.e. $/ \mathrm{n} / \rightarrow[\mathrm{m}] / /$ b/. The famous place assimilation rule for nasal (found in many languages like English, Spanish and Urdu with a little variation etc) states that nasal has the same place of articulation as the following consonant (Shah, 2002). For example, in the word (S)anbar 'a rich perfume', the place of articulation of the alveolar nasal $/ \mathrm{n} /$ is bilabial due to the following bilabial voiced stop. When alveolar nasal stop precedes bilabial voiced stop, it becomes bilabial nasal i.e. $/ \mathrm{n} / \rightarrow$ $[\mathrm{m}] /$ _ b. So the Arabic loans e.g. (S)^nb৯r 'a rich perfume'/ a proper noun(f), (S)^nbrin 'of

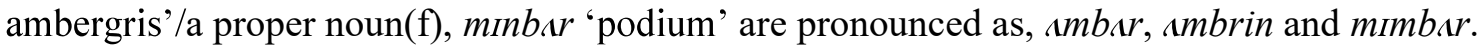
In the assimilation of $/ \mathrm{n} /$ and $/ \mathrm{m} /, / \mathrm{n} /$ becomes $/ \mathrm{m} /$ when it gets labialized. In all the examples, the voiced pharyngeal fricative $/ \mathcal{S} /$ is already neutralised as mentioned above.

The nasal is not necessarily followed by voiced bilabial stop $/ \mathrm{b} /$, and a nasal following bilabial stop is not the condition for the assimilation. The $/ l /$ of the Arabic definite article $a l / o l$ is also assimilated with the initial consonants of the following noun and the consonant is doubled. This can also be termed as elision of $/ 1 /$.

\section{Elision and Gemination}

Arabic consonants are divided into two groups, called the sun letters and moon letters based on whether or not they assimilate with the $/ l /$ of the definite article $a l / \sigma l$. The function of the definite article will be discussed in the sections to come. This section points out just the phonological aspect, found in Urdu the same as in Arabic i.e. $/ 1 / \rightarrow[\phi] / \ldots$ C.

When followed by some words beginning with the sun letters i.e. $/ t /, / \theta /, / d /, / \mathrm{d} /, / \mathrm{r} /, / \mathrm{z} /, / \mathrm{s} /$, $/ \mathrm{J} /, / \grave{\mathrm{s}} /, / \mathrm{d} /, / \mathrm{t} /, / \grave{\partial} /, / \mathrm{l} /$ and $/ \mathrm{n} /$, the $/ l /$ of $\partial l / o l$ is elided resulting in doubling the following consonant e.g. nurv $(l)$ ddin 'the light of the religion'. When the article is followed by some nouns beginning with the moon letters i.e. $|b /,| \check{g}|| h,|| h,|,| \dot{g} /,|f|,|q|,|k|,|m|,|w|,|y|,|h|$, this elision does not occur e.g. nurolkitab 'the light of the book'. The elision rule functions the same in Urdu also. The assimilation of lateral $\mathrm{J} / \mathrm{l} / \mathrm{\text {with }}$ the initial consonant of the following noun is specific with a proper noun. Note also that the elision of lateral $/ l /$ generally causes doubling the consonants, and the nouns after the elision are uttered as Riazo(1)ddin $\underline{\text { in }}$ etc. There may be some individual examples of elision and gemintaion, this the major aspect. The elision process is different from alternation of two consonants which sometimes swap their positions with each other. This swapping of each other's position is termed as metathesis.

\section{Metathesis}

Metathesis is a process where two sequenced segments in a word swap their sequence and show-up in different positions. Though not very frequent, Urdu contains some loanwords e.g. qufli/qulfi 'a jelly made of milk', which undergo metathesis. In the given word, note that, the fricative /f/ and the lateral /l/ have historically swapped each other within the Arabic loan. The word was actually spoken as qufli initially when it was borrowed. But due to some 
historical reasons, the two sounds /f /and / $/$ / were reversed, and in modern Urdu it is spoken as qulfi. Thus the word index has changed from $\mathrm{C} 1 \mathrm{~V} 1 \mathrm{C} 2 \mathrm{C} 3 \mathrm{~V} 2$ to $\mathrm{C} 1 \mathrm{~V} 1 \mathrm{C} 3 \mathrm{C} 2 \mathrm{~V} 2$, and the rule for it is:

$$
\begin{aligned}
& \text { qf/ } / \\
& \text { qufli }
\end{aligned} \quad \begin{array}{r}
/ 1 / \\
\text { qulfi }
\end{array} \text { 'a jelly made of milk' }
$$

However, the loanword examples of the consonantal swapping each other are very rare. The one discussed above is one of the major examples, which shows some rigorous phonological changes seen in the consonantal segments of the loanwords. In contrast to consonantal integration of loanwords, the changes in the vowels are only sometimes seen. There are some major vowel changes, but they are not as rigorous as seen in consonants. This work, however, will see just two of the major alternations of vowels taken place in the loanwords.

\section{Phonological Integration of Arabic Loans: Vowel Integration}

Due to the restrictions of space, this section is focuses on only two features of vowel change i.e. the vowel lengthening and the vowel shortening, and some others are left open for the future researchers.

\section{Vowel changes: Vowel Lengthening}

Deletion of a consonant in any word generally causes vowel lengthening. For example, the pharyngeal fricative e.g. $f(\varsigma) a l$ 'active' is neutralised in the Urdu words, and the words are actually spoken with long vowels as faal. Waqar \& Waqar (2002) consider this sort of lengthening (doubling/gemination of) the vowel, diphthongs. Analysing accoustic properties of diphthongs, they note that phonemically diphthongs do not exist in Urdu, but phonetically there are 13 diphthongs. In all the cases, they are formed from the deletion of the consonants: /S/, / $/, / \mathrm{j} /$ and /v/. However, diphthongs are not necessarily formed as a result of lengthening the vowel due to the deletion of preceding consonant. This can be seen in another Arabic loanword. As discussed above, the deletion of the voiced pharyngeal fricative $/ \mathcal{S} /$ from many Arabic loans e.g. $f a(\subseteq) r l$ 'subject/agent' causes the loan to be pronounced with the following vowel. Therefore, the loanword would be pronounced as farl. This causes the formation a dipthong $a$ I. Talking on vowel epenthesis and consonant deletion in loanwords in Akan, Adomako (2008) states, "Consonants, mostly liquids, are deleted when they precede other consonants as a member of word-final cluster. After such deletion, the preceding vowel is lengthened." However, as noted in the word, this is not the case in Urdu. The lengthening of preceding or following vowels is not necessary in Arabic loans in Urdu. This can also be noted in following the examples:

$$
\begin{aligned}
& \text { (C) Ilm } \\
& \text { - } \quad \mathrm{s} a(\mathrm{~S}) \partial \mathrm{t} \\
& \text { 'knowledge' } \\
& \text { sast 'moment' }
\end{aligned}
$$

\section{Vowel changes: Vowel Shortening}

The vowel shortening in the Arabic loans in Urdu is mainly seen in the pluralisation of feminine loan nouns with native plural markers. If a loan Arabic noun, treated as feminine, end in $-i$, it will be affixed with the plural marker $-j a$. But at the same time- $i$ has to be substituted by short front vowel $-_{-I^{-}}$. Consider the following examples: 


$\begin{array}{llll}\text { Nouns } & & \text { Plurals } \\ \text { 7a. korsi 'chair' } & \rightarrow \quad \text { korsıja } \\ \text { b. hazri 'presence' } & \rightarrow \quad \text { hazrija }\end{array}$

Note that in (7a) the noun is treated as feminine and, for the pluralisation, the feminine marker $-i$ will be substituted by the short vowel $-I$ - in the plural forms. The morphology here is in conformity with phonology, because it is not possible for long $-i$ to precede $-j a$, a suffix beginning with glide. The noun hazri in (7b) is the adapted feminine form of the loan noun/adjective hazIr '(someone) present'. Therefore, with the feminine marker $-i$, it fulfils the requirements of the pluralisation which ultimately shows the substitution by $-I^{-}$. Discussing some introductory features in Urdu, Naim (1999) states that Urdu long vowels are inherently long, similar to the vowels in cat and lord respectively, and all long vowels are pure, as they are not pronounced with a following glide. The feminine plural marker $-j a^{\sim}$ starts with a glide, and for this reason, the process of pluralisation necessarily requires the short vowel $-I^{-}$ which substitutes feminine marker $-i$ in singular nouns. Thus, it shows that there is a process of the shortening of vowels that does exist in Arabic loan nouns in Urdu.

However, the pluralisation is not the only process showing shortening of vowels. Sometimes, derivation of nouns from adjectives also shows similar shortening of vowels. Some adjectives ending $-i$ e.g. Ilmi 'literary/of knowledge' need a derivational affix $-j \partial_{n}$ to change into nouns Ilmijot 'learning/scholarship'. Note that as the derivational suffix $-j \partial_{n} t$ begins with a glide; the formation of noun requires the open coda vowel long $-i$ to change into short $-I^{-}$, the same as we see in the pluralisation. However, the adjective $I l m i$ is itself derived from the original base noun $I m$ 'knowledge/information' by the native Urdu derivational suffix $-i$. The adjective Ilmi is therefore a nativised form. As pointed out above in the native derivational affixes section, the derivational suffixes $-i$ also performs a quite reverse function. It derives nouns from base adjectives e.g. mehrum 'deprived' $\rightarrow$ mehrumi 'deprivation' which in turn can be transformed into another noun mehrumijat without any big change in the meaning. Note that the process of vowel shortening is the same. This also refers to nativised derivation of Arabic loans which contain the many interesting features.

\section{Phonology of Arabic Loanwords in Malay}

\section{Segmental adaptation}

Malay enforces various strategies in adopting foreign elements within its vocabulary to ease the transaction of loanwords. As seen before, the language ensures all foreign elements are substituted with similar phonemes or phonemes that show close similarities. Any vowel and consonant segments of the loanwords are altered significantly whenever necessary. Sound segments showing similarities between the source and native languages are adopted freely without severe modification. But sound-segments that are not found in the recipient language and those disobeying the natural phonology of the Malay are modified significantly. The forceful avoidance of alien sounds segments are aimed to ensure the received words exhibit more 'native essences'. The followings are the significant segmental adaptations noticed within the loan words. 


\section{Consonants}

As has been the norm of adaptation, recipient languages tend to accommodate source words within their native system more deliberately by relying upon their existing assets. Most of the similar sound segments are allowed freely in the adaptation, while the un-preferred soundsegments or un-represented sound-segments are assigned with newer segments showing similarities or approximate similarities.

In total, there are altogether five types of such modifications are witnessed in Malay

1) $\quad / \mathrm{q} / \rightarrow / \mathrm{k} /$

Malay language is lack of pharyngeal sound, hence, all ALW with pharyngeal sounds are adopted with voiceless velar sound $/ \mathrm{k} /$, which is the available immediate substitution from the dorsal region. There is an exceptionality - the holy text of the religion, Al-Quran, is adopted against the norm of loan adaptation.

$\begin{array}{lll}\text { Examples: } & & \\ \text { Arabic Origin } & \text { Malay Adaptation } & \text { Glossary } \\ \text { qaeda } & \text { kaedah } & \text { method } \\ \text { aqil } & \text { akil } & \text { wise } \\ \text { baqi } & \text { baki } & \text { remaining } \\ \text { həq } & \text { hak } & \text { right } \\ \text { qurban } & \text { kurban } & \text { sacrifice }\end{array}$

Notice that presence of pharyngeal /q/ in ALW is altered into voiceless velar $/ \mathrm{k} /$ by default, regardless to positions within the words. Intervocalically, the same also altered into voiced velar, $/ \mathrm{g} /$, as in the following.

Examples:

Arabic Origin Malay Adaptation Glossary

rəqəm ragam assorted

2) $/ \mathrm{x} / \rightarrow / \mathrm{kh} /$

The laryngeal sound velar fricative $/ \mathrm{x} /$ is not common in Malay. Hence loan terms having a laryngeal sound are substituted with simplified sound segments orthography, $/ \mathrm{kh} /$. The unrepresented sound segment is substituted with clustered consonant of velar, $/ \mathrm{k} /$, and fricative velar $/ \mathrm{h} /$.

Examples:

Arabic Origin Malay Adaptation Glossary

tarix tarikh date*

tawarx tawarikh history

3) $\quad / \mathrm{d}_{3} / \rightarrow / \mathrm{j} /$ and $/ \mathrm{d}^{\mathrm{j}} / \rightarrow / \mathrm{d} / / \mathrm{d}^{\mathrm{j}}$ alil $/$

Voiced affricate, $/ \mathrm{d}_{3} /$, is another sound segment that not fund within the inventory of sound segments in Malay. When a word with such sound is borrowed the recipient modifies the sound segments in accord to its native requirement. The voice affricate, 
$/ \mathrm{d} z /$, is lenited to become voiced palatal $/ \mathrm{j} /$, while the voiced affricate, $/ \mathrm{d}^{\mathrm{j}} /$ is accepted in simplified voice dental form, /d/.

Examples:

Arabic Origin

Malay Adaptation Glossary

modzlis

majlis

assembly

dzahil

jahil

ignorant/naive*

hadiir

hadir

present

4) $/ \mathrm{v} / \rightarrow / \mathrm{w} /$

Another sound segment subjected to rigorous modification is the voice labio-dental, $/ \mathrm{v} /$, which is not present in the phonemic inventory of Malay. The segment is adopted as labio-dental glide $/ \mathrm{w} /$.

Examples:

Arabic Origin

vakil

Malay Adaptation

wakil
Glossary

representative

5) $\quad / \mathrm{sh} / \rightarrow / \mathrm{s} /$

The last type of phonemic modification is coronalisation. Post-alveolar retroflex fricative, $/ \mathrm{sh} /$ is simplified as alveolar fricative $/ \mathrm{s} /$ in adaptation as well.

Examples:

Arabic Origin ash'kar

Malay Adaptation askar
Glossary

soldier

\section{Vowels}

Malay thrives in every possible ways to accommodate borrowed terms with most suitable vowel segments or that of showing similarities between the donor and borrower language. Though Malay show flexibility in receiving majority of vowel segments, /a,e,i,o,u/ as per see, their allophonic counterparts, especially/a/, is subjected to major modification. The half-open middle vowel, schwa, undergoes at least three types of modifications; loan words with syllabified schwa at the word-initially are replaced with back Front Open vowel ,/a/, in wholesome, while the Front Narrow /e/ also altered in similar way in some cases. The schwa at word-final syllable positions are modified with, both the Front Back /a/ and Narrowed Back $/ \mathrm{u} /$.

6) Adaptation of $/ \mathrm{a} / \rightarrow$ /a/ word-initially

$\begin{array}{lll}\text { Arabic Origin } & \text { Malay Adaptation } & \text { Glossary } \\ \text { vəkil } & \text { wakil } & \text { lawyer/representative } \\ \text { mədzlis } & \text { majlis } & \text { assembly } \\ \text { həq } & \text { hak } & \text { right } \\ \text { Jək } & \text { syak } & \text { doubt }\end{array}$


7) Adaptation of $/ \mathrm{a} / \rightarrow / \mathrm{a} /$ word-finally

$\begin{array}{lll}\text { Arabic Origin } & \text { Malay Adaptation } & \text { Glossary } \\ \text { məslək } & \text { masalah } & \text { problem } \\ \text { məzhəb } & \text { mazhab } & \text { religion } \\ \text { rehmət } & \text { rahmat } & \text { blessing } \\ \text { rəqəm } & \text { ragam } & \text { amount/kind* } \\ \text { rəsəm } & \text { resam } & \text { tradition }\end{array}$

8) Adaptation of $/ \mathrm{a} / \rightarrow / \mathrm{u} /$ word-finally

$\begin{array}{lll}\text { Arabic Origin } & \begin{array}{l}\text { Malay Adaptation } \\ \text { maksəd }\end{array} & \begin{array}{l}\text { Glossary } \\ \text { aim/purpose }\end{array}\end{array}$

Besides the schwa, the Back Narrow, /u/ in some cases is also altered with Front Open, /a/. Note that classic example/rokən/ adopted as /rakan/, 'member/friend' has relinquished, both the Back Narrow $/ \mathrm{u} /$ and schwa in syllable initial and final, respectively. This sort of alteration might be the resultant of vowel copying or vowel harmony as well.

However, in one instance the Malay seemed to be comfortable in accepting Front-Narrow, /i/, as Front Open, /a/, into its vocabulary.

9)

\begin{tabular}{|c|c|}
\hline $\begin{array}{l}\text { Arabic Origin } \\
\text { harīm }\end{array}$ & $\begin{array}{l}\text { Malay Adaptation } \\
\text { haram }\end{array}$ \\
\hline
\end{tabular}

A final remark of the segmental adaptation is on adaptation morphology with Back HalfNarrow segment, /o/. The data at hand, /soltān/ $\rightarrow$ /sultan/ 'ruler', shows that the language does not prefer to retain the segment within loan terms; Malay altered the segment into Back Narrow, /u/, at the end of adaptation.

\section{Metathesis $^{5}$}

Metathesis is a process where two sequenced segments in a word swap their sequence and show-up in different positions. In one instance, the Malay has adopted metathesis to accommodate necessary language-specific requirement. Notice that the $/ \mathrm{u} /$ in loanword /kursi/ 'chair', has swapped it place to form open-ended word-medial syllable. The prohibited onset-cluster is now avoided by vowel epenthesis, /e/.

\section{2.2.3.1.5. Metathesis}

Metathesis is not a frequent exercise in Urdu. It contains some loans such as e.g. qofli/qulfi 'a jelly made of milk', which undergo metathesis. In the given word, note that, the fricative /f/ and the lateral /1/ have historically swapped each other within the Arabic loan. The /f/and /1/ in the actual spoken word, qufli, has been subjected to reversion due to some historical reasons in modern Urdu it is spoken as qulfi. Thus the word index has changed from $\mathrm{C} 1 \mathrm{~V} 1 \mathrm{C} 2 \mathrm{C} 3 \mathrm{~V} 2$ to $\mathrm{C} 1 \mathrm{~V} 1 \mathrm{C} 3 \mathrm{C} 2 \mathrm{~V} 2$, and the rule for it is:
1) /f/
$\underset{\text { qufli }}{\Leftrightarrow} \quad / 1$
qulfi
'a jelly made of milk' 


\section{Vowel lowering}

Malay also considers Vowel Lowering (VL) as a strategic approach of harmonising the adaptation. VL, where a particular vowel segment lowered from one position to another, is another aspect of adaptation of vowel segment. The example, /bhindi/ 'okra' with onset clusters and Front Narrow, /i/ has undergone lenition in two ways. The language has dropped the sonorous segment within the onset-cluster, and lowered the vowel from Front Narrow to Half narrow segment, /e/.

\section{Syllable Modification and structural well-formedness}

Earlier we have seen that Malay is a $\mathrm{C}-\mathrm{V}-\mathrm{C}$ orientated language and it avoids complex consonants $\left({ }^{*} \mathrm{CC}\right)$. Any loans with illicit syllable form that not conform to its expectations are 'repaired' in due to ensure all borrowed terms are received in language-friendlier manner. The adaptation processes can be paralleled as the Theory of Constraint and Repair Strategy (TCSR) suggested by Paradis, (1996), Paradis and LaCharte (1997). The illicit syllables forms clustered-segments are nativized using strategic cluster breaking methods. Clustered consonant are detached by adding a convenient vowel from the same region as proposed by (Hayes (1990), Clements (1995) and so on which argues that vowels can be assigned with place nodes as well; /i/ and /e/ are coronal, the /u/ and /o/ are labial and /a/ is velar.

\section{Onset clusters}

Onset clusters in the ALW violating the requirement of the language are modified to fit the phonological criteria of the Malay, in the following ways.

i. Deletion

$\begin{array}{lll}\begin{array}{l}\text { Arabic Origin } \\ \text { sharāb }\end{array} & \begin{array}{l}\text { Malay Adaptation } \\ \text { sirup }\end{array} & \begin{array}{l}\text { Glossary } \\ \text { a drink }\end{array}\end{array}$

Malay inserts a Front-Low /a/ to break onset-cluster as well.

ii. Insertion of a vowel

$\begin{array}{lll}\begin{array}{l}\text { Arabic Origin } \\ \text { njis }\end{array} & \begin{array}{l}\text { Malay Adaptation } \\ \text { najis }\end{array} & \begin{array}{l}\text { Glossary } \\ \text { /excrement }\end{array}\end{array}$

\section{Coda Clusters}

Coda-Clusters are severely avoided in Malay. The following strategies are applied to avoid the cluster with special preference given to specific sound segments in general.

i. Malay does not prefer voiceless dental/t/ at word-finally monosyllable words, unless it is a final segment of a disyllabic or polysyllable word, as in $/$ rehmott $\rightarrow \mid$ rahmat 
'blessing'. ALW not fulfilling this requirement are syllabified either as onset or coda of the second syllable, as in (x).

Examples:

Arabic Origin

waqt

mot

$\begin{array}{ll}\text { Malay Adaptation } & \text { Glossary } \\ \text { waktu } & \text { /time } \\ \text { maut } & \text { death }\end{array}$

Note that the word final / $/$ / has been altered to become onset in the first two examples, while in the last example; it has been syllabified as coda of the second syllable (ma.ut 'death').

ii. Epenthesis insertion is another popular way of breaking up the coda-clusters. As has been mentioned the language inserts vowel segment from same region of either one of the clustered consonant.

Examples:

Arabic Origin

itr/utur

masjd

Malay Adaptation Glossary

atar perfume

mufls

masjid

/mosque

muflis

/bankrupt

shukr

syukur

/thankful

sifr

sifar

/ zero

iii. The language also drops either one of the clustered consonant. There are cases where

the vacant space is compensated with additional vowel, as is prevalent in the second example.

Examples:

Arabic Origin

hadd

maff

$\begin{array}{ll}\text { Malay Adaptation } & \text { Glossary } \\ \text { had } & \text { limit } \\ \text { maaf } & \text { /sorry }\end{array}$

\section{Emphasis}

Certain ALW are known for preferring emphasis. Since emphasis is not a distinctive feature of Malay. Therefore, the words with emphasis are modified to standard forms, with relinquished emphasis, as in $(\mathrm{x})-$

1) Drop of prefix

Arabic Origin

Qur-ban

Malay Adaptation

korban

ash'kar

askar

Glossary

sacrifice

soldier 


\section{Stress and Vowel Qualities}

Malay has a simple stress system. All word-initial open syllables are stressed in monosyllable and disyllable words, while the antepenultimate open syllable is stressed in the tri-syllabic words. Combination of both stressed patterns is preserved in the polysyllable words. Hence, ALW that evades these requirements are modified in two ways, vowel lengthening and vowel shortening.

Stress bearing ALW are dealt slight differently in the recipient language. ALW carrying stress on the word-final syllables are altered in two ways. One is by shortening the duration of vowel segments in the final syllable, as in /sàbuun/ $\rightarrow$ /sabun/ 'soap', and the other is by deleting component of the word-initial syllable, as in the followings, /mawsim/ $\rightarrow / \mathrm{musim} /$ 'season'

Borrowing and word-Minimality

It is rather intriguing to note that Malay prefers to adopt loanwords in binary forms but not in monosyllable forms. Borrowed terms having monosyllable forms are modified into disyllabic forms in the adaptation ${ }^{6}$. This requirement can be seen in the followings.

1) Examples:

$\begin{array}{lll}\begin{array}{l}\text { Arabic Origin } \\ \text { maff }\end{array} & \begin{array}{l}\text { Malay Adaptation } \\ \text { ma.af }\end{array} & \begin{array}{l}\text { Glossary } \\ \text { /sorry }\end{array} \\ \text { sifr } & \text { si.far } & \text { / zero } \\ \text { waqt } & \text { wak.tu } & \text { /time } \\ \text { mot } & \text { ma.ut } & \text { death }\end{array}$

Notice that the monosyllable ALW surface as disyllabic resultants.

In the foregoing section we have seen the phonological adaptation of ALW, in what follows we will see how the ALW are morphologically adopted within the grammar of recipient languages.

\section{The Morphology}

\section{Brief Introduction to the Morphology of Urdu}

Urdu distinguishes two genders (masculine/feminine) \& singular/plural numbers and three cases of direct, oblique, and vocative. Most nouns are marked. For example, the feminine noun bəkri 'goat' is marked for plural as bəkrija ' 'goats'. There are also a tiny number of unmarked nouns, which cannot be changed structurally e.g. gao 'village/villages' (m) and $\mathrm{pao}^{\sim}$ 'foot/feet' $(\mathrm{m})$. Both nouns are invariable and function with no morphological changes regarding gender/number, unlike all others which morphologically variable. Mostly a suffix is added to the base, which sometimes undergoes some alternation as well. Moizuddin (1989) uses some criteria to classify the plural patterns in particular and other word categories in general as: 1) There are declinable and indeclinable variations i.e. those whose structure can

${ }^{6}$ There is an exception, the ALW /had/ 'limit' does not fall within this category. 
and cannot be changed. For example, bəkra 'goat' (m) is a declinable noun, because it can be changed structurally for plural form i.e. bəkre. But gao 'village/villages' (m) is indeclinable noun, because it remains unchanged in its plural form. 2) Many structural changes are based on concordial relations i.e. gender/number agreement. Note that the masculine noun bəkra has a feminine form bəkri. This shows that there gender/number are changes in Urdu nouns. 3) There are structural changes based on also their colligation (relation) with clitics/case markers e.g. ergative ne and dative/accusative ko etc. For example, the plural noun bakre is also the oblique form of the singular noun, while the oblique form of the plural noun is bəkro . The oblique form must be must be marked for oblique case by means of the ending $o \sim$ and followed by a case marker. Most important are the changes in the pluralisation of nouns in relation with masculine and feminine gender morphology. In order to understand the plural morphology of Persian and Arabic loans, it is necessary to see the gender/number morphology of the native noun.

Making computational analysis of Urdu morpho-syntact categories, Hardie (2003) states, "Urdu inflection is based on suffixation; the suffixes are fusional, consisting overwhelmingly of a single syllable, or even a single vowel, that may mark multiple features e.g. gender, number and case are marked on nouns". For example, bəkra (m), bəkri (f), bəkre and bəkrija are the masculine and feminine and their plural forms of the same noun 'goat'. As can be seen, the gender and number of the noun are generally indicated by the final vowel $-a,-i$ and $e /-I j a \tilde{a}$, which are the major gender/number markers for masculine and feminine nouns. Most nouns end in $-a$ for masculine, and so they end in $-i$ for feminine. There are often irregularities in every gender/number patterns. First consider below gender difference:

Masculine Noun

1a. larka 'boy'

b. bhəygi 'toilet cleaner'

c. $u \tilde{t}$ 'camel'

$$
\text { all other (m) suffixes } \rightarrow-n i
$$

Feminine Noun

lorki 'girl'

bhaygan

uัtni

Note that the feminine gender morphology mainly depends upon the masculine gender morphology, and show many structural changes. There seems to be a correlation between the morphology of masculine and feminine noun. If a masculine noun ends in $-a$ e.g. beta 'son' and (1a), feminine noun will take inflection $-i$ e.g. beti 'daughter'. Though most native masculine nouns end with $-a$, a considerable number of these nouns also end with different suffixes particularly $-i$ as in (1b). If a masculine noun ends in $-i$ e.g. bhəygi 'toilet cleaner', a feminine noun will take suffix -ən e.g. bhaygən 'female toilet cleaner' etc. Whatever the suffix all other masculine nouns take e.g. $u^{\tilde{t} \boldsymbol{t}}$ 'camel' and bhut 'ghost' etc, their feminine noun will take inflection -ni i.e. ütni and bhutni etc, as in (1c).

These are the major gender markings, for animated objected, and frequently occur. There may be some occurring less frequently. Rizvi (2007) states, "There is no general rule for gender classification for inanimate nouns. Usually huge, heavy, powerful, dominant and bigger things are masculine, while smaller, weak and lighter are feminine". He further states that on the basis of morphology, it is very difficult to make rules distinguishing gender that encompasses all combinations. However, above from this perception, a large number of nouns i.e. those of plants and inanimate objects and which have no gender marker are

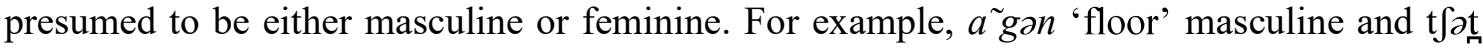
'roof/ceiling' is feminine. Many crops are also traditionally treated as either masculine or feminine. For example, beng $\wedge$ 'brinjal' is masculine and gadzor 'carrot' is feminine. As can 
be seen, it is though not necessary in every case, most inanimate nouns also take the markers $-a$ and $-i$ for gender difference. For example, sona 'gold' is masculine and tfand $i$ 'silver' is feminine noun. Gender marking is often used to show the size i.e. masculine for bigger and

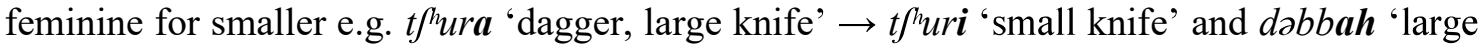
box' $\rightarrow$ dabbi 'small box'.

\section{The Gender/Number Morphology of Arabic Loan Nouns}

This section discusses gender, number morphology of Arabic loans in Urdu and their deviations from both native and Arabic patterns. The focus is on three major things. After some description of gender, the plural morphology of Arabic loan nouns is discussed in detail. It includes both sound plurals and broken plurals. Then there is some discussion on irregularities and deviations from the specific patterns of plural formations.

Although there may be a larger number of Persian loans in Urdu, there are more gender/number adaptations in Arabic. The adaptations are also little more complex than we have seen in native Urdu and Persian loans. Arabic gender is basically grammatical not natural. Therefore all Arabic nouns are classified in feminine and masculine. Like in Urdu, the gender distinction of a large number of nouns in Arabic is based on presumption. Arabic concept of masculine gender as the ground gender already exists in the most Urdu nouns, but it is also vice versa. It is usually said that the origin regarding nouns is masculinity, in Arabic, and femininity is a branch. That means, according to word composition, a noun is masculine unless it takes a feminine marker or shows gender marker in Arabic. For example, the noun kItab 'book' and korsi 'chair' are masculine and Jəms 'sun' and buhera(h) 'lake/sea' are feminine. However, the presumption is not necessarily the same in Urdu e.g. kitab and korsi are treated as feminine and fams and bohera(h) are taken as masculine. Besides, Arabic differentiation of masculine and feminine in the singular/dual, male humans, female humans and non-human plurals people has also not entered the same in Urdu. There is no gender distinction based on non-human singular or plurals, but Arabic loanword gender markers are however separate for singular and plural.

There are two main Arabic masculine suffixes for singular i.e. $-a(h)$ and $-i$. The first $-a(h)$ is already in conformity with Urdu $-a$, as discussed above. The other $-i$ is also in fact in conformity with the Urdu feminine marker $-i$, but used in rare cases for masculine e.g. bhəygi. It is however the major native feminine marker e.g. larki 'girl'. The only Arabic gender marker that has actually entered Urdu is feminine $-a(h)$ e.g. taliba 'female student'. To differentiate it from masculine, it is said that there is in fact an underlying $/ t /$ in Arabic ${ }^{7}$, but not in Urdu. There is a confusion for the learners of Urdu whether a masculine noun ending with a rhotic will be feminised with native $-n i$ or Arabic $-a(h)$. It is difficult to decide, and requires some background knowledge of nouns. In native Urdu, a masculine with rhotic ending e.g. lohar 'blacksmith' is generally feminised with -ni i.e. loharni. In Arabic loans, there is a correlation of masculine endings in $-m /-r$ and feminine noun $-a(h)$. e.g. farr 'poet'/farra(h) 'poetess'. Discussing computational grammar for Urdu, Rizvi (2007) points out that $-a(h)$ is mostly used for feminine nouns in Urdu. Feminine noun is even little more popular than masculine plurals. The following subsection discusses this.

There are two Arabic masculine plurals i.e. -un e.g. alamun 'world' for subject position and in e.g. alamin for object position, and one feminine plural -at. e.g. talıbat. 'Female student', but the masculine plural -in and the feminine plural $-a t$ are known in Urdu. However, there

7. Conversation with a speaker of Arabic. 
have been major adaptations of loan plural nouns. Most loan nouns appear with native gender morphology. Not necessarily both masculine and feminine or their plurals are used in Urdu. Sometimes, only masculine/feminine or any of their plural is used. Very frequently any of the forms are used together with the native plural forms. Only rarely is an Arabic loan noun used with all of its masculine/feminine singular and plural forms. Very briefly, the following sketch illustrates the loan gender/number markers.

\section{Linguistic Examples:}

\section{Masculine}

a) SaIr 'poet'- Plural unchanged $\rightarrow-a(h) \quad$ farra(h) 'poetess'

b) talıb talıban 'seekers/students' -in $\rightarrow-a_{n} \underset{n}{t} t_{n} a l_{I} b a(\boldsymbol{h})$ 'female student' talıbat (Plural)

c) nafir 'Publishers' nafirin (pl) -in $\rightarrow-a t$

Note that in (6a) the loan noun is used with both of its genders, but their plurals are not known. In (6b), note that the primary meaning of the base word is 'seeker'. It is not used with the meaning of 'student' that is used with the other forms of the word. As said, the masculine plural is generally used with the suffix -in. Therefore, a masculine plural with the suffix -an is unusual. However, the masculine plural tolba(h) is not also on native Urdu Pattern. The feminine is used with the singular form talıba(h) and the plural talıbat 'female students'. The third example (6c) also shows that only masculine singular nafIr 'publisher' and the plural form are common in Urdu, while the feminine forms are unknown. It is also important to say that masculine plurals are those of adjectives, which can often be used as nouns as well. For example, mahrr 'expert' is actually an adjective, but also used as noun. Its plural can be mahrrin 'experts' (m), but its feminine is not used in Urdu and so it's plural is also not possible. As a whole it can be said that the loan pluralisation is however not exactly the same as it is seen in Arabic. However the plurals with these two markers are not the only plural forms borrowed from Arabic. There is some other Arabic loanword pluralisation in Urdu.

\section{Structural Changes in Arabic Loan Nouns: Sound Plurals}

Discussing phonological and morphological integration of loanwords in Egyptian Arabic, Hafez (1996) states that there are two types of plural inflections. One is suffixal and regular, traditionally termed as sound plural with the two realizations -in e.g. mahır 'expert'/ mahirin for the masculine and -at e.g. talıba(h) 'student'/talibat for the feminine. Second is the broken plural e.g. qalb 'heart'/qolub, usually leading to insertion, deletion, and vowel change, and often an indication of maximal integration of a word into the language. Although Hafez's (1996) discussion is in relevance with Egyptian Arabic, this distinction also occurs in standard Arabic as a whole. Urdu has borrowed both of these types of plurals either directly or via Persian. As noted, more important thing is that the sound plural markers, for masculie and feminine, i.e. -in and-at are not generally used with the same noun. Mostly, they are used with different nouns. Consider first the following table:

Table 3. Arabic Loan Nouns and Their Plurals

\begin{tabular}{|l|l|l|l|l|}
\hline No. & Masculine Nouns & Plural & Feminine Nouns & Plural \\
\hline $\mathbf{1}$ & mahır 'expert' & mahırin & talıba(h) 'student' & talıbat \\
\hline
\end{tabular}




\begin{tabular}{|c|c|c|c|c|}
\hline 2 & hazir 'present' & hazIrin & ajat t'verse' & ajat \\
\hline 3 & mərz 'disease' & omraz & qIst 'instalment' & әqsat \\
\hline 4 & tarix 'history' & təvarix & xatun 'woman' & xəvatin \\
\hline 5 & vəkil 'lawyer' & vokla & orət 'woman' & orate $^{\sim}$ \\
\hline 6 & məqsəd 'aim/purpose' & maqasid & mədzlıs 'assembly' & mədzalıs \\
\hline 7 & həq 'right' & hoquq & rəqəm 'money' & raqum \\
\hline
\end{tabular}

Note that among the seven, the first two examples represent sound plurals, and the rest represent broken plurals. The feminine sound plurals are generally formed with the

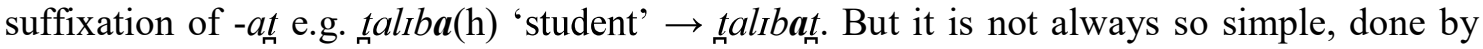
adding the suffix - at, only. Sometimes, a base noun ends with -jat. In this case, for the plural, there is an alternation of vowels, and the schwa sound $\boldsymbol{\partial}$ is substituted by long $\boldsymbol{a}$ e.g.

7a. $x a$ sijot 'quality' $\rightarrow$ xasijat,

- b.xasıjot 'quality/nutrition' $\rightarrow$ quality/nutrition

- c. ajat 'verse' $\rightarrow$ ajat.

Note that the three plurals seem to be on the same patterns, but the three singular nouns have different endings from $-a(h)$, which is however general ending for singular feminine nouns. Arabic are nouns traditionally used as adjectives, as well, or vice versa. Arabic pluralisation of adjectives is also observable in Urdu and, not necessarily nouns, but also certain adjectives are inflected with the same plural markers for the plurals e.g. baqi 'remaining' $\rightarrow$ baqijat 'remains'. This is particularly seen in masculine plurals i.e. -in is mostly suffixed with adjectives, and very few times with any noun:

8a. same 'listener' $\rightarrow$ samein 'listeners'

- b. nazIr 'watcher/seer' $\rightarrow$ nazIrin 'audience'

- c. hazIr 'present' $\rightarrow$ hazırin 'spectators/those who are present'

Note that the three plurals are generally formed by adjectives. Gender/number morphology is a feature of Urdu, but a plural adjective is not traditional in native Urdu. This feature is mainly the influence of Arabic. Many of the base loans are very commonly used as adjectives rather than nouns. Their plurals e.g. same $\rightarrow$ samein 'listeners' are however used as nouns.

The sound plurals with the two plural markers i.e. -in and - $a t$ are just one aspect of Arabic loan pluralisation. Urdu has borrowed not only sound plurals but also broken plurals. Most loan plurals are in fact broken plurals, and are formed depending on the substitution, insertion and deletion of vowels. It is also interesting to note that many masculine/feminine loan nouns e.g. farr 'poet' take Arabic pattern of broken plural in one gender i.e. fora 'poets', but the native plural markers in the other gender i.e. Sarra $e^{\sim}$ 'poetesses'. Further, they often take both the plural patterns i.e. native and Arabic. 


\section{Morphological Changes in Arabic Loan Nouns: Broken Plurals}

Traditional grammars of Arabic distinguish between two modes of plural formation, the sound plural with plural markers (as discussed above) and the broken plural, which primarily involves internal modification of the base noun by vowel change i.e. insertion, deletion and substitution e.g. nafs 'soul'/nəfus 'souls'. Broken plural is a distinctive feature of Arabic and other Semitic languages. Talking on the grammar of words, Booij et al (2007) term the modification of base as revowelling and state, "Arabic belongs to Semitic language family, and the Semitic languages are unique in their reliance on revowelling i.e. changing the form of words by replacing the vowels in them". This process of pluralisation by the alternation of vowel is generally a feature of standard Arabic that is termed as classical Arabic, as well. As they point out, Radcliffe (1990: 113) states in his discussion of Classical Arabic, "brokenplural inflection is rather complicated as it follows several different patterns that involve inserting infixes, deletion, and vowel change." The fusion of Arabic loan broken plurals is the most challenging pluralisation in Urdu. It is complicated, as it follows different patterns that involve vowel insertion, deletion and substitution. Some of patterns can be observed as given below:

9a. (द)əmir (m) 'rich' $\rightarrow$ (ৎ) omra

b. qəlb (m) 'heart' $\rightarrow$ qulub and

c. mədzlis (f) 'assembly' $\rightarrow$ mədzalis

Note that all the three examples represent three patterns of broken plural, but they all commonly show that the plural formation as a whole depends on vowel change in the base. The first example (9a) shows three features i.e. the substitution of schwa sound /a/ with short round vowel $/ \mho /$, deletion of long front vowel $/ \mathrm{i} /$ and an insertion of long vowel $/ \mathrm{a} /$. The second example (9b) shows two things i.e. the substitution of $/ 2 /$ with short round vowel $/ \mho /$ and an insertion of long round vowel $/ \mathrm{u} /$. The third example (9c) just shows an insertion of long $/ a /$. Though the three examples contain different syllables, a large number of such loan nouns are single syllable and inanimate.

There are five major patterns of broken plurals commonly used in Urdu, and all show substitution, deletion, and insertion of vowels irrespective of gender difference. However, there may be some minor changes, regarding masculine and feminine gender, within the same pattern. Consider the following table:

$\begin{array}{lll}\text { Table 4: Major Changes: 1) } \varnothing \rightarrow ð & \text { 2) } \not \rightarrow a & \text { 3) } \varnothing \rightarrow v\end{array}$

\begin{tabular}{|c|c|c|c|}
\hline Mas: Noun & Loan / Native Pl. & Fem: Noun & Loan/Native: PI \\
\hline 1-mərz 'disease' & amraz / marz & yərz 'interest' & ayraz / yərze \\
\hline 2- qol 'saying' & aqval / qol & qom 'nation' & aqvam / qomer \\
\hline 3- mal 'wealth' & amval / mal & $m o t$ 'death' & amvat / mote \\
\hline 4- rokan 'member' & arkan / arakin /rokan & $\bmod 3$ 'wave' & $\operatorname{amvad} 3 / \bmod 3 \boldsymbol{e}^{\sim}$ \\
\hline $5-$ & - & qIst 'installment' & oqsat / qIster \\
\hline
\end{tabular}


Note that though original noun patterns may not be similar, but the process of pluralization in all examples is the same. There may be deletion of the round vowels e.g. /o/ in qol/qom (2) or $/ \mho /$ in rokən (4). There may also be an insertion e.g. $/ \partial /$ and $/ v /$ in $\partial m v a l$ and $/ a /$ in $\partial r k a n$, but there is certainly a vowel redistribution. All examples reveal one plural pattern containing two vowels /a/ and /a/ playing key role. The plurals begin with schwa /a/ and then after two consonant long back vowel $/ a /$ takes the position. Note also that, like their native counterparts, the patterns of the loan plurals are similar to each other.. The fourth example shows various features of the alternation of vowels in the tri consonantal base. It is different from others in that it shows the general alternations of vowels, but some plurals also show deviation from both source language (Arabic) and the target language (Urdu). Note in (4) that the actual plural is arkan and the native plural remains unchanged, but it is also used as arakin, as having the sound plural marker. A closer look of the noun rokan, and its plural formation, from a different angle reveals that arakin contains the sound plural marker -in. It is distinctive in the sense that its plural arkan is also commonly used with a restructured form arakin. This shows that -in is mixed up in the Urdu pluralisation, and it now seems to be a native plural marker.

A further interesting element is an insertion of a labio-dental fricative $/ v /$ in some loans e.g. qol 'saying' (m)/aqval, but not in others. This seems to be in fact mainly due orthography. In both Urdu and Arabic $/ o /$ and $/ v /$ are written with the same letter. Following a consonant, it functions as round vowel $/ o /$, but preceding any vowel, it represents $/ v /$. Thus, for example, the Urdu word to 'then' becomes tova 'an iron plate for baking chapatti'. In the given example, the letter is single in the Arabic script, but it is performing both the functions of $/ o /$ and $/ v /$. For this reason, it can be said that the main changes are phonologically and morphologically different but orthographically they seem to be the same. However, orthography is not the major source of change. Generally, there is an insertion of vowel and sometimes a consonant.

This can also be observed in another pattern of broken plurals, in which there are two processes together i.e. infixation of a vowel-consonant morpheme $\partial v$ and the deletion of long vowel $a$. However, there is difference of gender. Some feminine patterns avoid deletion. This means infixation of schwa and fricative is constant and regular , but the deletion is irregular and depends on whether there is final vowel $a$ :

Table 5. 1) $[\varnothing] \rightarrow \partial v / A_{-} \# \quad$ 2) $[a] \rightarrow \varnothing /$ dental $_{\text {\# }}$ (masculine)

\begin{tabular}{|c|c|c|c|}
\hline Mas: Noun & Loan / Native Pl. & Fem: Noun & Loan / Native: PI \\
\hline 1-faeda & fovaed / faede & fahIfa'prostitute' & favahIf / fahifae \\
\hline 2- qaeda & qavaed / qaede & xatun 'woman' & xəvatin / *xatune \\
\hline 3- rabıta (*rabița) & rovabit / rabite & nəfil 'addi: prayer' & nəvafil / nafil \\
\hline 4- & - & tarix 'date/history' & tovarix / tarixe \\
\hline
\end{tabular}


Note in (1) that there is long /a/ word finally in most nouns, and it is deleted in the plural forms, but it does not exist in most feminine nouns. This is also not clear whether and which particular type of nouns have long $a$. The deviations are seen only in feminine nouns. Generally, one thing is clear i.e. the insertion of a vowel-consonant morpheme $\partial v$, a combination of schwa and labiodental fricative in the feminine plural e.g. nəfIl 'additional prayer' $\rightarrow$ nəvafil (3). Note that the feminine noun shows three elements deviating from this general regular pattern of broken plurals. One, note that, long $a$ does not exist, and so there is no deletion. Two, schwa already exists in the base noun, and so fricative $v$, in combination with long $a$, forms morpheme that is infixed for the pluralisation. Three, the insertion of long $a$ word medially is also a deviation from the general pattern.

There are some examples though, the broken plurals of this pattern are not generally seen with many feminine nouns. Among the few examples, this is interesting to see that a Turkish loan feminine noun xatun 'woman' (2) has also the broken plural xəvatin. The other loan broken plurals have their native counterparts as well, but interestingly the Turkish loan xatun has not integrated in the native morphology. Therefore, the use of native plural *xatune is ungrammatical, though the other nouns take the native plural marker $/ e^{\sim} /$ as seen in the table. This is unlike all other nouns in the pattern. Note also the that the insertion of the morpheme $\partial v$ in the plural is according to general pattern, but the alternation of vowel i.e. the substitution of $u$ by $i$ shows deviation from this. In contrast, it is interesting to note that the Arabic counterpart orot 'woman' is equally common in use, but it takes native Urdu plural orote rather than broken plural * orat, which is ungrammatical in Urdu. The only difference between the use of both the Arabic and Turkish singular nouns is that the Turkish noun xatun expresses more respect and more formal language. Arabic pluralisation with a Turkish loan noun may be because Arabic has also had influence on Turkish. This again shows that the change vowel is not constant in the pattern.

This can also be witnessed in some plurals of adjectives/adverbs as well e.g. lazIm 'necessary' $\rightarrow$ lovazım 'necessities', which is an interesting entrance in Urdu. Further, interesting is the affxation of the Arabic plural marker - at with broken of plural lovazim It is, though, not uncommon, the inflection of $-a t$ is even more common i.e. lovazimat, which is however not the Arabic plural and not even the native plural form. This affixation of the sound plural marker - $a t$, with even an Arabic broken plural shows its complete fusion in Urdu so much so that not only it attaches to the naive bases but also the loan bases. This means that the Arabic loan plural markers -in and - at are completely fused with native bases. Most attachmenst are by $-a t$, which is feminine plural marker. Feminine plurals in this pattern are however limited to hardly few in number, but with many structural changes, while masculine plurals are in a variety by only those formed by adjectives and adverbs.

In contrast, masculine plurals are not so simple in another pattern, showing various alternations of vowels e.g. vəkil 'lawyer' $\rightarrow$ vokla. Note that there is a substitution of schwa $/ a /$ with round vowel $/ \mho /$. At the same time there is also a deletion of front high vowel $/ i /$ and an insertion of long back vowel and $\boldsymbol{a}$ in the coda. This is a general picture in this pattern, but there is nevertheless some deviations seen. Consider the following table summarizing the pattern. 
Table 6.

\begin{tabular}{|l|l|c|c|}
\hline Mas: Noun & Loan / Native Pl. & Fem: Noun & Loan/Native: PI \\
\hline 1- vəkil ‘lawyer' & vokla / vəkil & - & - \\
\hline 2- vəzir 'minister' & vozra / vəzir & - & - \\
\hline 3- dzahıl 'ignorant' & dzohla / dzahıl & - & - \\
\hline 4- $a$ qıl ‘wise' & oqla / aqıl & - & - \\
\hline
\end{tabular}

Note that in some nouns, front high short vowel /I/ may be seen in the base nouns rather than long front high vowel $\boldsymbol{i}$, but the changes will be on the same pattern e.g. aqIl 'wise' $\rightarrow$ oqla etc. In general, it can be seen that round back vowel $/ \mho /$ substitutes $\partial / a$ in the onset cluster, while $/ i /$ or $/ \mathrm{I} /$ is deleted with an insertion of back long low vowel $/ a /$ in the word final position. This alternation of vowels remains the same in all the nouns of this class. As all the base nouns are masculine ending with a closed coda. The native counterparts of the loan plurals also remain the same as previously noted. Both native and loan patterns are though commonly used, the native ones are in higher frequency.

All the examples show that the substitution is indefinite whether $a$ or $a$ by $v$. However, it is for sure that whatever exists must be substituted by the short round vowel $/ \mho /$ in the plural forms. Similarly, it is also an uncertain whether $/ i /$ or $/ I /$, but the deletion itself is certain. The third important element to see is that the insertion of long $/ a$ / is certain. As a whole it can be said that the base nouns may differ from each other e.g. vazir 'minister' and $d z a h \boldsymbol{I} l$ 'ignorant', they however develop the same plural pattern that is very simple and the same in the broken plurals.

A rather simpler alternation of vowels is seen in feminine nouns of the next pattern of broken plural that just needs an insertion of a long back vowel /a/ in the onset position in the feminine plurals. However, the masculine plurals are little more complex. Consider the following table:

Table7.

\begin{tabular}{|c|c|c|c|}
\hline Mas: Noun & Loan / Native PI. & Fem: Noun & Loan/Native: PI \\
\hline 1- mazhab 'religion' & mazahıb / mazhab & tod dbir 'plan' & todabir / tod dbire \\
\hline 2-məqsəd 'aim/purpose' & maqasid / maqsad & tadzviz 'proposal' & tadzaviz / tadకvize \\
\hline 3- maslak'problem' & masalık / maslak & madzlis 'assembly' & madzalis / madzlise \\
\hline 4- molk'country' & mamalık / molk & mənzIl 'destination' & manazıl / manzıle \\
\hline
\end{tabular}

Note that all the base nouns are generally formed of two syllables, and schwa forms the core. However, there are certain things that avoid the base nouns, generally required for this 
pattern. One, some masculine nouns e.g. molk 'country' can be completely irregular. Two, there is a difference of long $/ \mathrm{i} /$ and short $/ \mathrm{I} /$ in the coda, which however does not affect the pluralisation. The process of forming plurals however seems very simple, according to which, a masculine noun requires only the substitution of schwa/a/ by long /a/ in the first syllable e.g. maslak 'problem' $\rightarrow$ masalık. The schwa in the second syllable is replaced by short front vowel $/ I /$. The irregular base nouns also entails the same plural structure. The feminine plural varies a little. As it already contains front $/ \mathrm{i} /$ or $/ \mathrm{I} /$ in the second syllable e.g. tod ${ }_{n} b i r$ 'plan' $\rightarrow$ tzdabir, there is no change. The whole alternation of vowels for the plural shows that the pattern of pluralizing is though same, the masculine and feminine broken plurals nonetheless show a clear difference. While feminine noun needs only an insertion of a long vowel $/ a /$, the main requirement of masculine noun is also to substitute schwa /a/ with a short front $/ I /$ in the codas.

Schwa /a/ has again a key role in the base nouns of some other broken plurals in a pattern. While the base nouns seem to be completely differing from each other, the broken plurals show some regularity. However, there is a clear difference of structure in the masculine/feminine plurals. Consider the table:

Table 8.

\begin{tabular}{|c|c|c|c|}
\hline Mas: Noun & Loan / Native Pl. & Fem: Noun & Loan/Native: PI \\
\hline 1- qalb 'heart' & $q \boldsymbol{\sigma} l \boldsymbol{u} b / q \partial l b$ & raqəm 'amount' & raqum / raqumat /raqวme \\
\hline 2- $ә m \partial r$ 'mater' & omur / $\partial m \partial r$ & 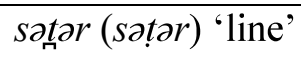 & satur / satare \\
\hline 3- $\int \partial k^{\prime}$ 'doubt' & fokuk. / fok & rasam 'tradtion' & rasum / rasumat /rasame \\
\hline 4- həq 'right' & hoquq / haq & vadza(h) 'reason' & vadzuh/vadzuhat /vadza(h)e \\
\hline
\end{tabular}

Note that most masculine nouns are mono syllabic e.g. qalb 'heart' unlike the feminine ones which are bi syllabic e.g. raqam. There are also some deviations from within each of the two classes of the nouns. There is one major difference in the plural formations as well. Note that like the feminine plurals, masculine plurals need an insertion of long back round vowel $/ u /$, but it also substitutes schwa /a/ with round vowel/ø/ e.g. qolub in the onset. Schwa/a/ however retains its position in the onset of feminine nouns which only require a substitution of schwa by the long round vowel $/ u /$ in the coda. All nouns generally follow this rule in both the genders, but there is some deviation as well.

Note that the one major difference in some masculine plurals e.g. fokuk or hoquq is the consonant doubling in the plurals. This is however not the sort of germination (doubling) as seen usually i.e. two consonant in a sequence e.g. in English noun cattail 'a kind of herb'. Almost all base nouns need two or more consonants in coda. To fulfil this need, the second consonant is repeated. Discussing morpho-phonological integration of loanwords into Egyptian Arabic, Hafez (1996: 10) points out that one of the recurrent phonological patterns is gemination, i.e. consonant doubling. This is seen in standard Arabic, as well, and so Arabic loans in Urdu. This is a common feature of bi-consonantal nouns.

Seemingly masculine and feminine plurals are different from each other, there are certain exceptions that some masculine plurals behave exactly the same as feminine plurals. For example, compare the two gender plurals. An substitution of schwa /a/ by long / $u /$ in the coda 
e.g. sotar 'line' $\rightarrow$ sotur (f) is a feature of feminine plural, but a masculine noun e.g. nəq $\int$ 'mark/impression' $\rightarrow$ nəqu $\int(\mathrm{m})$ shows a consistent deviation form the rules in general. Masculine plurals are much bigger in number and have a variety of structural changes. Feminine plurals show fewer alternations of vowels. There are also some other minor avoidances, in the general rule.

In sum, as noted, many of Arabic nouns following the borrowed rule of broken plural also follow the native plural rule. This means the two masculine nouns i.e. omir (m) 'rich' and $q a l b(\mathrm{~m})$ 'heart' are unchanged in their Urdu native plural forms, according to native morphology of Urdu masculine plural, because base noun ends with other than $-a$. Similarly, the feminine noun madzlis (f) 'assembly' can also be pluralised in native manner requiring plural marker $-e^{\sim}$ i.e. madzlis $\tilde{\boldsymbol{e}}$, according to the native need. The reason for preferably applying native plural rule, by the general public, is because the broken plurals are hard and confusing. They are however frequently used, and are not very uncommon. Most importantly, it is also noted that many broken plurals also take loan plural markers i.e. -in and -at. This is further discussed in the next section.

\section{Sound Plurals, Broken Plurals and Native Plurals}

Arabic loan nouns in number are not as many as Persian loan nouns or native nouns. But they show a variety of morphological changes in the plurals as a whole. The plural patterns are in two groups. There are sound plurals of masculine and feminine nouns ending in -in and -at respectively, whose adaptation is evident in many examples observed. Then, there are five commonly used patterns of broken plurals showing insertion, deletion and substitution of vowels. There may be rigorous differences between base nouns, but the morphological changes are similar within each class of broken plurals, and there is a set pattern to which the nouns follow. The speakers of Urdu are generally aware of Arabic pluralisation strategies particularly those of sound plurals. Not very commonly, but they use broken plurals as well. The use of broken plurals does not influence their behaviour with respect to Urdu pluralisation. It is generally observed that speakers feel it very convenient to use an adapted plural rather than loan broken plural. However, the integration of loanwords into native morphology with the frequent deviation from set patterns is interesting for the observation of linguists.

The most interesting and unique feature in the broken plurals is that many broken plurals take the further plural marker -in or - at (particularly), and so they are generally used as sound plurals e.g. vadzuh $\rightarrow$ vadzuhat. This is a concrete evidence that the Arabic sound plural markers have been completely adapted and so are frequent. They are attached to native nouns and even Arabic broken plurals. Consider the table:

Table 9a. Feminine Nouns

\begin{tabular}{|l|l|l|l|}
\hline Noun & Broken Pl. & Sound Plural & Native Plural \\
\hline 1- rəqəm 'amount' & rəqum & rəqumat & rəqəme \\
\hline 2- rəsəm 'tradtion' & rəsum & rəsumat & rəsəme \\
\hline
\end{tabular}




\begin{tabular}{|c|c|c|c|}
\hline 3- vadza(h) 'reason' & vadzuh & vadzuhat & $\operatorname{vad} z a(h) \boldsymbol{e}^{\sim}$ \\
\hline 4-tzarıb 'mater' & taqarib & taqribat & taqribe \\
\hline
\end{tabular}

Table 9b. Masculine Nouns

\begin{tabular}{|c|c|c|c|}
\hline Noun & Broken PI. & Sound Plural & Native Plural \\
\hline 1- rokan 'member' & orkan & arakin & rokan \\
\hline 2- mafriq & məsarıq & mafriqen & $m \partial / r i q$ \\
\hline 3-dzohər' 'quality' & dzəvahIr & dzəvahırat & dzohər \\
\hline 4-ləqəb & alqab & alqabat & laqab \\
\hline 5- lazIm (adj) 'necessary' & lavazim & lovazImat & - \\
\hline
\end{tabular}

Note that all Arabic loans e.g. rokan (m) 'member' have two plurals i.e. arkan (Arabic) and arakin/rokan (Urdu). The alternation of vowels in the broken plural arkan is not as rigorous as in its adapted plural arakin. The actual native plural form rokan is unchanged. Such examples show that adaptation process is very deep, and cannot be termed as minor modification. This is even more evident from the feminine nouns that are more frequently used e.g. rasam (f) 'tradition' $\rightarrow$ rasum/rasumat (f) etc. The first of the pair of the plurals is loan broken plural and the second is the adapted pattern. The indigenous native pattern of

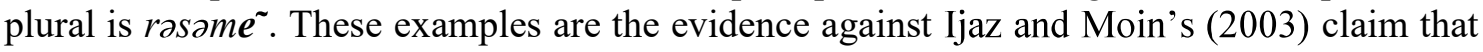
there are well defined rules. Urdu lexicon is rich of such examples showing morphological variations and different plurals of the same nouns. The variations very often show deviations from the norms. It is mainly because of the existence of a large number of loan nouns used.

\section{A Brief Picture of the Pluralisation of the Urdu Noun after Adaptation of Loan}

The complete picture that emerges from the above discussion is that Urdu native nouns have some gender/number rules, but there is frequent divergence from the rules. Further, there are Persian and Arabic loanword patterns, but they also often adopt native gender/number markers. Persian loans particularly adopt native gender, as Persian is devoid of any gender marking. However, the loans are fully integrated with native morphology and with each other. For example, the feminine marker $-a(h)$ in Persian loan noun adakara $(\boldsymbol{h})$ 'actress' is in fact Arabic loan, because many Persian loans follow major Arabic feminine pattern e.g. Saera(h) 'poetess' that is also a loan in Urdu. Such integration causes more than one plural forms of the same noun.

It is often observed that the loan nouns and their plurals deviating from their original pattern integrate with native morphology or vice versa. This is particularly interesting to see in broken plurals which sometimes take sound plural markers. Consider the three nouns and their plurals:

\section{Linguistic Examples: Set 10.}

10a. hakım 'ruler' $\rightarrow$ i) hakımin / ii) hokam / iii) hakım 'rulers/authorities' b. xadrım 'servant' $\rightarrow$ i) xudam / ii) xadmin / iii) xadrim 'servants' 


\section{c. lazım '(something) essential' $\rightarrow$ i) ləvazım / ii) ləvazmat 'essentials'}

The three examples of the amalgamation of broken plurals with sound plurals and native plurals show various features. Note that, in (10a), there are three Arabic masculine loan nouns and each has at least two plurals of which the first is the loan and the second (and the third) is the form adapted in Urdu. Note that although the basic structures of the three nouns are similar, their plurals are showing some sort of deviation from the original Arabic and the native Urdu pattern. Note that (i) and (iii) in each example follows Arabic pattern and native Urdu pattern respectively, but (ii) deviates from both. The broken plurals are taking further morphological changes, and are also behaving differently from pluralisation in Arabic.

The three examples also show that, if the noun is masculine and not ending in $-a$, the plural is generally unchanged in the adapted plural form. The nouns in (10) deviating from their respective source language pattern (Arabic/Persian) and the target language pattern (Urdu) taking different plural forms are the evidence against Naim (1999) who claims that original Persian and Arabic nouns are never inflected. They are also evidence against Ijaz \& Moin's (2003) claims that there are well defined rules. The patterns of the nouns are the same in the base form, but their pluralisation vary from each other. The examples also illustrate that a noun particularly loan noun may have more than one plural i.e. there may be partially and completely adapted form. For example, hokam (10a.(ii)) and xadmin (10b.(ii)) are partially adapted, because the integration is not exactly according to native pattern. The other unchanged plurals xadrm and hakım are fully adapted forms, because native masculine nouns, other than ending in $-a$, are unchanged.

A loan noun may deviate from its respective origin and is sometimes partially or completely integrated. According to the analysis of Wegener (2004) about loanword integration, Winter (2008: 158-159 ) points out in Studying Loan Words and Loanword Integration: Two Criteria of Conformity, we obtain three different stages of morphological integration: 1) inflection according to a non-native pattern, 2) inflection according to a peripheral target language pattern, 3) inflection according to a native target language pattern. The examples above show that the first plural in each is according to non native pattern. The second is peripheral integrated plural form, as it is not following native rule. The third is according to target language pattern. Therefore, it can be claimed that Urdu morphology is not restricted to native gender/number patterns. Rather, there are some elements of Persian and Arabic morphology as well. There is often amalgamation of the three morphologies. Sometimes the morphological integration is so deep that it is difficult to decide between the native and the loans. Certainly the reason of such integration, and very often two or more plural forms, is because some Arabic loan nouns have entered Urdu via Persian. The morphological changes are not restricted to either of the two origins, i.e. Persian and Arabic, and many of the loanwords undergo significant changes. Such as the root word of xabar 'news' is an Arabic loan and is used in Persian as well, but some morphological patterns in Urdu are different from those of Persian and Arabic. This shown below in the modified form of comparison made by Riaz, (2007:5):

11a. $x ə b \partial r$ 'news' in Urdu, Arabic and Persian-root form

b. axbar 'newspaper' in Urdu and Persian, but plural of 'news' in Arabic

c. axbarat 'newspapers' in Urdu and Persian

d. $x a b r e^{\sim}$ 'news(plural)' in indigenous Urdu 
Note that the tri consonantal Arabic root word xabər entered Urdu via Persian, but it has undergone various structural changes, and the morphological patterns are both loans and indigenous Urdu. Its Arabic plural axbar is commonly used in both Urdu and Persian, but with different semantics i.e. 'newspaper'. axbar is considered as singular noun, and its plural is axbarat 'newspapers' that is not the member of Arabic lexicon. Arabic singular noun xəbər 'news' has an indigenous Urdu plural xəbre that is strange in both Arabic and Persian.

As seen the morphological changes in Urdu noun show a variety of features. As they are in relation with the different origin of nouns, they frequently deviate form the rules. However, whatever are the nouns, the morphological changes according to Case will follow mainly native rule, though there is a possibility that a loan plural noun e.g. axbarat 'newspapers' may remain unchanged in its oblique form.

\section{Introduction to morphology of Malay in brief}

A brief introduction to the morphological system of Malay is vital for current exploration. Malay words can be categorised in few ways. Winstedt (1927) categorised Malay vocabulary into - major and minor classes. Words such as substantive nouns, adjectives and verbs fall within the major class, while pronouns, numerals, adverbs, propositions, conjunctions, and interjections are classed as minor class. Zainal (1947) believe that the language has four class of words - noun, verb, adjective, conjunctions and interrogatives. Nik Safiah (1987) argues that Malay has the followings; i) Nouns and pronouns, ii) Verbs (transitive and intransitive), iii) Adjectives and iv) Function Words. The comprehensive list given by Major Dictionary Work done by language standardization body (Kamus Umum Besar Melayu Dewan) has added an additional category, adverb within it.

The nouns are divided into four different classes.

i) Special noun

ii) Ordinary nouns

iii) Pronouns

iv) Direction

v) Address (gelaran)

All nouns are singular and they make no apparent reference to gender, except for a few gender referral terms, such as /ayah/ 'father', lemak/ 'mother, labang/ 'brother', /kakak/ 'sister', /lelaki/ 'man/boy', /perempuan/ 'woman' /gadis/ 'girl' and so on. In general it can be termed as gender bias language just like Arabic, but not gender specific language like Urdu and others.

\section{Structural changes in Arabic Loan Nouns}

In adaptation some of the loan words are structurally modified to fit within the morphological system of recipient language. Malay applies two structural modifications to ALW that challenge its popular structural organisations; one is simple modification and comprehensive modification ${ }^{8}$. Simple modification is enforced with drop of affixes which are unfamiliar to

${ }^{8}$ The comprehensive modification allowed the structure to modify the received structure in
'more' complete structural form. The ALW are modified by adding additional morphemes, as 
its morphological system, and those do not contribute semantic revelations. Whenever, there is a base morphology of the capability of rendering intended semantic independently, it tends to drop prefixes. The prefix relinquishing targets prefix /al/ 'holy' in general. Again, there is exceptionality - the holy religious manuscript, Al-Quran, is adopted without modification.

1) Drop of prefix

Arabic Origin

Al-khamis

Al-Ahad

$\begin{array}{ll}\text { Malay Adaptation } & \text { Glossary } \\ \text { Khamis } & \text { Thursday } \\ \text { Ahad } & \text { Sunday }\end{array}$

Change of morphological class in Arabic Loan Nouns

Loan words are adopted to perform specific functions in the recipient language. Since a specific term is selected and loaned in the borrower term, therefore, changing of morphological classes is regular strategy of loan-word adaptation in Malay. Majority of the loans have been received as what they are in the donor language within the same morphological class, except for a few. Concrete nouns have been received as abstract nouns, as the followings.
Arabic Origin
vəkil
Malay Adaptation wakil
Glossary
representative (but not lawyer)

The term, /vakil/, is an Arabic proper noun, but the same term has been received as an abstract noun in Malay.

Ahmad wakil sekolah saya.

Ahmad is representative of my school.

Apart from this example, we could not notice any significant changes of morphological class within the given list of words.

Pluralisation of Arabic Loan Nouns
a. Urdu
b. Malay

Pluralisation is language-specific demand and carried-out in designated forms to support speakers' need. Whenever the pluralisation system of loanword and native word differ significantly, the recipient language employs restrictions and ensures the received loan word function within their pluralisation framework. Adaptation of the loanwords within the framework of recipient language shows some significant outcomes, as well. Malay ensures the borrowed terms adhere to compulsory native-friendlier methods of multiplications. This section elaborates on pluralisation of ALW within the framework of Malay grammar.

in /gao/ $\rightarrow$ /kampung/ 'village' and /tang/tange / $\rightarrow$ /'tangan'/ 'hands' which has been added with additional syllables, /pung/ and / an/ respectively, to render the sense of 'village' in Malay. Unfortunately, we did not come across with examples from ALW exhibiting such kind of modifications. 
Malay has a non-complicated plural system. The system is not-complicated like other agglutinative languages, like Urdu, Tamil and so on which applies various suffixes, infixes, and broken plurals and so on. The language pluralises its vocabularies in four common ways, namely,

1) i. Total and Partial Reduplication

ii. Irregular duplication

iii. Addition of post-lexical numeral adjective

iv. Suffixation

We shall see them in order.

Reduplication is the most common and simple way of inducing plural connotation to any noun regardless to gender and generic differences. Examples of total or partial reduplications are as follows.

1) Total reduplication

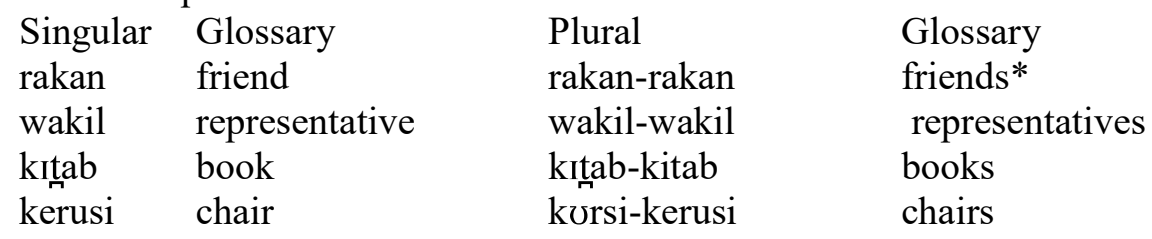

2) Partial reduplication

$\begin{array}{llll}\text { Singular } & \text { Glossary } & \text { Plural } & \text { Glossary } \\ \text { *tulis } & \text { write } & \text { tetulis } & \text { write many time } \\ \text { *baik } & \text { good } & \text { bebaik } & \text { being good } \\ \text { *cepat } & \text { fast } & \text { cecepat } & \text { switfly }\end{array}$

(* not loan words. They are native verb, adjective and adverb, respectively)

As it is transparent, total and partial reduplications enlarged the semantic connotation of the singular forms. Total reduplications have copied the entire lexical forms, while that of the partial have copied the initial-syllable with slight modification done on the vowel, vowel rising.

Irregular duplication is also an equally important strategy of connoting sense of multiplication. Certain loan terms are forced to undergo irregular duplication, shows no systematic patterns of reduplications. As in the case of following examples, /saki-baki/ 'balances' /syak-wasangkal '(many) suspiciousness', some of these terms copy the final syllable of the base-word while the initial syllable is altered to coronal-friendlier fricative (as in the case of the former), while some are attached to newer lexical, which could not render any semantic on its own (as in the case of the latter). ALW are not exceptional to irregular duplications.

The third strategy, addition of numerals and quantifier adjectives, is the popular strategy of all. Specific quantifier adjectives usually applied to nouns related human and non-human. Addition of post-lexical numeral adjective /banyak/ 'a lot' and /sedikit/ 'less' is applied for non-human lexical, while post-lexical numeral adjective such as /ramai/ 'many' is applied to 
connote sense of plural to human-related nouns. Almost all nouns, the native and loan, easily adopt one of them without much hassle as substitution for reduplications.

The last strategy, suffixation, is a reserved practice of pluralisation. It is used along with human-related nouns; non-human nouns are only allowed to adopt one of the three strategies mentioned in the foregoing. Suffix /in/ is attached to derived nouns to render plural sense, often, as in the followings.

1) Suffixation of Derived nouns with /am/ and /in/

$\begin{array}{llll}\text { Singular } & \text { Glossary } & \text { Plural } & \text { Glossary } \\ \text { hadir } & \text { present } & \text { hadirin } & \text { those presence }\end{array}$

In this section we have seen how ALW are pluralised in Malay by enforcing it grammatical requirements and pluralisation framework. In what follows we shall see another method of nativisation of adopted terms, grammaticalisation.

Grammaticalisation (Place-Number-Gender (PNG Markers)) of Arabic Loan Nouns

Malay has a simple morphological system account for nominal concatenation and gender difference. Lexical items are not distinguished for number and gender, instead of that, all lexical are singular and gender free in this language. Based on this, however, is cannot be classed as a gender bias language. It pays lesser attribute to account for gender differences like what is apparent in most of the Indo-European languages, like Germany, French, Arabic, Urdu and so on.

\section{i. Number}

Number distinction is characteristics of Arabic Nouns, in which the nouns are internally inflected at least in three categorical distinctions - singular, dual and plural. The categorical distinction is devised through morphological concatenation. The concatenated words posit some challenges when they are transferred into recipient language. As we have seen in the case of Urdu, the distinction is copied in specific ways observed within recipient language; where the triplet categorical distinction brought down to two. Interestingly, transferring numeral categorisation is not an issue in Malay, as the language does not distinguish its vocabularies into numeral categories. All nouns in Malay are considered singular and receive loan words in singular forms, alone.

However, it applies different strategies to preserve it numeral distinctions. As the case of pluralisation, after the terms were pluralised, they were added with additional suffixes to connote numeral distinctions. For example - /muslim $\rightarrow$ musliman or muslimin, the /an/ suffixation refer to masculine and the /in/ refer to feminine.

\section{ii. Gender}

In general Malay Nouns do not do not offer any gender reference or make any gender distinction as well. Except for a few gender specific words, such as /ayah/ 'father', /abang/ 'brother', /lelaki/, 'boy /man/, lemak/ 'mother', kakak 'sister', /perempuan/ 'lady/girl', /wanital 'woman', most of its nouns are gender-free terms. In most of the case the gender differences are derived from contextual references, as in the case of the followings.

1) Dia budak perempuan yang baik. 
She is a good girl.

Dia minum air.

She drink water.

Dia budak lelaki yang baik.

He is a good boy.

Dia minum air.

He drink water

Note that the noun /budak/ is qualified by /perempuan/ and /lelaki/, refer to girl and boy respectively. The pronoun / dia/ is gender free; its gender reference can only be understood in relative context. Following the rule of majority, loans are received in the singular forms and they are assigned with gender qualification in language specific manner.

\section{Semantic changes of Arabic Loan Nouns}

Semantic alteration is not an issue for most of the borrowed terms, as they usually brought-in to serve the same semantic purposes within the recipient languages. However, this criterion is needed not to be fulfilled at all time. Malay has 15 ALWs, that not satisfying these borrowing criteria. The following are the terms experienced absolute semantic alterations, of which reason is remained unknown.

\section{Semantic Changes in Urdu and Malay}

3) Arabic Origin

\section{Concrete Nouns}

Origin

alım (alm?)

askar

nazIr

rokən

vəkil

sharāb
Malay Adaptation

Urdu Adaptation

alım

askar

nazIr

rokən

vəkil

sharāb
Glossary

\begin{tabular}{lr} 
Malay Adaptation & \multicolumn{1}{c}{$\begin{array}{l}\text { Glossary } \\
\text { scholar/wise } \\
\text { alim }\end{array}$} \\
askar & army/soldier* \\
nazir & watchers/observer* \\
rakan & member/friend* \\
wakil & lawyer/representative* \\
sirup & alcohol drink/a drink*
\end{tabular}

Ahad

tarikh

tawarikh

the one/Sunday*

history/date*

histories/history*

lazim

tadbir

plan/for a

Nouns Related to Action

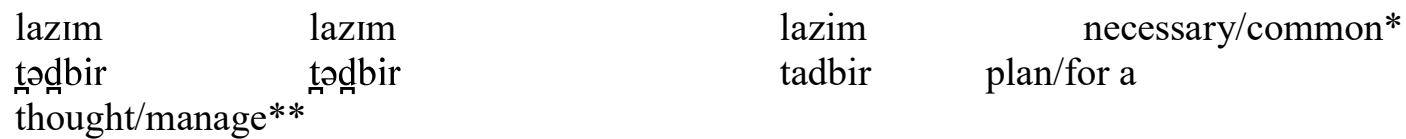

Nouns Related to Quality

dzahıl dzahıl

jahlil/jahil ignorant/stupid* 
Abstract Nouns

$\begin{array}{lllr}\text { məqsəd } & \text { məqsəd } & \text { maksud } & \text { aim/meaning* } \\ \text { rəqəm } & \text { rəqəm } & \text { ragam } & \text { amount/kind* } \\ \text { vədza(h) } & \text { vədza(h) } & \text { wadzah } & \text { reason/instrument* }\end{array}$

* ( / ) shows the semantic difference in recipient languages, orderly, in Urdu and Malay

As given in the glossary, these terms connote different semantics in Arabic, but in the course of adaptation their semantic revelation has been altered ${ }^{9}$. The term /vakil/, on the other hand, has been used to refer a representative instead of lawyer in Malay (lawyer is referred as peguam in Malay). Obviously, both of the terms have undergone radical changes. It was an unfortunate because we are in position of not able to verify the period of these semantic changes came into effect in the recipient language.

\section{Conclusion}

In this paper we have offered an overall explanation for a set of nouns that have been borrowed from Arabic which have been accommodated and adaptation in fashionable ways within Malay and Urdu. Both languages seemingly have been benefitted from the donor language, but never been loyal in receiving the recipient term. Almost all loans have been altered either phonologicall or morphologicall to ensure the loaned terms respect the general sound system and structural order of the languages. Again, this proved that in loaning terms, the receiver is at upper hand in ensuring the loan protocal to be adopted in any situation, the donor abide to these restrictions. The study also shows how rigourous was the adaptation procedures imposed by the languages, before allowing them to serve their loan purpose, serve the language in effective communition.

\section{Bibliographies/ References}

Abbi, Anvita. 1985 Reduplicative Structures: A Phenomenon of the South Asian Linguistic Area. Oceanic Linguistics Special Publications, No. 20, For Gordon H. Fairbanks (1985), pp. 159-171

Adomako, Kwasi. 2008 Vowel Epenthesis and Consonant Deletion in Loanwords: A study of Akan. MA Thesis. University of Tromso.

Ahmed, Rizwan. 2008. Unpacking Indexicality: Urdu in India. Texas Linguistic Forum 52: 1-9. Proceedings of the Sixteenth Annual Symposium about Language and Society - Austin

Ahmed, Tafseer. 2008. Instrument as Path: Reconciling the semantic usages of Urdu se and Pashto pa. Workshop on "Morphosyntactic Aspects of Instruments and Instrumentals" Universität Konstanz

Aronoff, M. 1976. Word Formation in Generative Grammar, MIT Press

Awang Sudjai Hairul \& Yusof Khan. 1990. Kamus Lengkap, Kuala Lumpur. Pustaka Zaman. Aziz, Omar 2002. Nasal Aspirates in Urdu. Centre for Research in Urdu Language Processing (CRULP), National University of Computer and Emerging Sciences,

${ }^{9} \mathrm{ALW} /$ tang/ which used to refer legs has been adopted to render the semantic of hands (legs are referred as 'kaki' but nothing else in Malay). 
Lahore, Pakistan.

Bauer, Laurie. 2003. Introducing Linguistic Morphology. Edinburgh: Cambridge

University Press

Bauer, Laurie. 2005. English Exocentric Compounds, University of Wellington.pp-7

Bhatia, T. K. \& Ashok Koul: 2000. Colloquial Urdu: The Complete Course for Beginners. London and New York: Routledge, pp358

Bogel, T. M. Butt, A. Hautli, and S. Sulger. 2007 Developing a Finite-State Morphological Analyzer for Urdu and Hindi: Some issues. In FSMNLP 07 (Finite-State Methods and Natural Language Processing)

Booij, Geert. 2007. The Grammar of Words: An Introduction to Linguistic Morphology Oxford: Oxford University Press [2nd edition].

Bokhari, Sohail. 1985. Phonology of Urdu Language. 1991. Urdu Zubaan ka Soti Nizaam (The Sound System of Urdu Language).

Bukhari, Nadeem. Haider.2009. The Syntax of Serial Verbs in Gojri. PhD Thesis, Newcastle University.

Butt, Miriam. 2003. Tense and Aspect in Urdu Journee' d'etudesle Temps etl'aspect, Paris.Revised Edition for ParGram Meeting, Dublin

Butt, Miriam, and Tracy Holloway King. 2005. The Status of Case. In V. Dayal and

A. Mahajan (Eds.), Clause Structure in South Asian Languages. Oxford: Oxford University Press.

Butt, Miriam, \& Tracy Holloway King. 2006. Restriction for Morphological Valency Alternations:The Urdu Causative- Center for the Study of Language and Info:

Carlisle, J. F.1987. The use of morphological knowledge in spelling derived forms by learning disabled and normal students. Annals of Dyslexia

Clark, John and Yallop Colin.1999. An Introduction to Phonetics and Phonology. Blackwell Publishers.

Cysouw, Michael. 2003. The paradigmatic structure of person marking. Oxford University Press, New York.

David et al. 2009. Urdu Morphology.

Davenport, Mike \& Hannahs, S.J. 2005 Introducing Phonetics \& Phonology, 2nd edn. London/New York: Hodder Arnold/OUP.

Durani, Nadir. 2007. Typology of word and Automatic Word Segmentation in Urdu Text Corpus. M.S Thesis Submitted to National University of Computer \& Emerging Sciences. Lahore, Pakistan.

Ghazali, M. A. Urdu Syllable Templates, Centre for Research in Urdu Language Processing, Islamabad.

Gillon, Brandon.S. 1996. Exocentric (Bahuvr ${ }^{-}$Ihi) Compounds In Classical Sanskrit McGill University

Hafez, Ola. 1996. Phonological and morphological Integration of Loanwords into Egyptian Arabic. Égypte/Monde arabe, Première série, 27-28 383-410.

Hardie, Andrew. 2003. The Computational Analysis of Morpho-Syntactic Categories in Urdu, PhD Thesis Submitted to Department of Linguistics and Modern English Language Lancaster University

Hussain, S. 1997. Phonetic Correlates of Lexical Stress in Urdu, Unpublished PhD, Dissertation, North-western University, IL, USA.

Hussain, S. \& M. Afzal. 2001. Urdu Computing Standards: Urdu Zabta Takhti (UZT 1.01). Proceedings of IEEE International Multi-Topic Conference, Lahore, Pakistan. Ijaz and Moin. 2003. Gender and Number Generation of Urdu Nouns. CRUL (CENTER FOR 
Research in Urdu Language Processing, islamabad) Annual Student Report

Kachru, Y. 1990. Hindi-Urdu. In: Comrie (1990)

Kachru, Yamuna 1990.Hindi-Urdu in The Major Languages of South Asia, The Middle East and Africa, edited by Bernard Comrie.

Kashif Munir and Tayyaba Mohsin. 2003. Existence of Ingma in Urdu Language and its Phonological Features. Akhbar- e -Urdu (Urdu Magazine. Muqtadra Qaumi Zuban Urdu Language Authority, Islamabad, Pakistan. June Edition.

Kashif, Derakhshan. 2004. Jadeed Dersee Urdu 'Modern Urdu Teaching' Qamer Kitab Gher. Urdu Bazar Karachi.

Keane. 2001. Echo Words in Tamil. PhD Thesis Submitted at Trinity College, Oxford.

Kenstowicz, Michael. 1994.Phonology in Generative grammar. Cambridge, MA: Blackwell Khan, Mahboob Alam 1997. Urdu ka Soti Nizaam (The Sound System of Urdu).- Centre for Urdu Research

Koul, Omkar. N. 2008. Modern Hindi Grammar. Dunwoody Press, McNeil Technologies, Inc. Springfield, USA.

Ladefoged, Peter. 1993. A course in phonetics. 3rd edition. Fort Worth, TX: Harcourt, Brace, and Jovanovich.

Laver, J 1994. Principles of Phonetics. Cambridge University Press.

Lehrer, Adrienne. 2000. Are Affixes Signs? The Semantic Relationship of English Derivational Affixes. In Morphological Analysis in Comparison. By Dressler Wolfgang U. John Benjamins Publishing Co. North America

Lieber, Rochelle \& Sergio Scalise 2006. The Lexical Integrity Hypothesis in a new Theoretical Universe. Lingue e Linguaggio V.1. 7-32.

Ohala, Manjari (1999), "Hindi", in International Phonetic Association, Handbook of the International Phonetic Association: A Guide to the Use of the International Phonetic Alphabet, Cambridge University Press, pp. 100-103,

Olsen, Susan. 2000. Copulative Compounds: A Closer Look at the Interface Between Syntax and Morphology. Yearbook of Morphology

Mohanan, Tara. 1994. Argument Structure in Hindi. PhD Thesis-Stanford, CA: CSLI Publications. Dissertation in Linguistic Series

Moizuddin, Mohammad. 1989. Word Forms in Urdu. National Language Authority Islamabad. (Submitted as an MPhil Thesis in 1967-University of London)

Montaut, Anni. 2009. Reduplication and 'echo words' in Hindi/ Urdu. de Gruyter Reference Global

Murrell, G.A. and Morton, J. 1974. Word Recognition and Morphemic Structure. Journal of Experimental Psychology 102, 963-968

Naim, C.M. 1999. Introductory Urdu. Volume I. Revised Third Edition. South Asia Language and Area Centre. University of Chicago.

Plag, Ingo. 1999. Morphological Productivity: Structural Constraints in English Derivation.

- $\quad$ Mouton, de Gruyter.

Raza, Agha Ali. Mansoor Pervaiz \& Waqas Iqbal 2003. Existence of Velar Nasal Stops in Urdu. Akhbar- e-Urdu (Urdu Magazine. Muqtadra Qaumi Zuban Urdu Language Authority, Islamabad, Pakistan. June Edition.

Rehman, Tarique. (2003) Linguistics in Pakistan Centre for Urdu Research, Islamabad Pakistan.

Rehman, Tarique. (2003) Linguistics in Pakistan Centre for Urdu Research, Islamabad Pakistan.

Riaz, Kashif. 2007 Challenges in Urdu Stemming (A Progress Report), University of Minnesota, Minneapolis, Page 5. 
Rizvi, S. M. J. 2007. Development of Algorithms and Computational Grammar for Urdu. $\mathrm{PhD}$. Thesis, Pakistan Institute of Engineering and Applied Sciences.

Saleem, Abdul Manan. Kabir, Hasan. Riaz, Mohammad Khuram. Rfique, Mohammad Mustafa. Khalid, Nauman. Shahid, Syed Raza, 2002-Urdu Consonantal and Vocalic Sounds-Centre for Urdu Research

Schmidt, Ruth Laila. 1999. Urdu: An Essential Grammar. London. Routledge

Seidenberg, M.S., \& Gonnerman, L.M. (2000). Explaining Derivational Morphology as the Convergence of Codes. Trends in Cognitive Sciences, 4 (9), 353-361.

Shahid, Syed Raza. 2002. A Study on Stop in Urdu. Centre for Urdu Research, Pakistan

Shah, Syed Mustafa. (2002). Urdu Nasal Consonant and Phonological Behaviour, Akhbare-Urdu (Urdu Magazine), Muqtadra Qaumi Zaban Urdu Language Authority, Islamabad Pakistan, April-May Edition

Shapiro, Michael C. (2003), Hindi in Cardona, George \& Dhanesh Jain (eds.), The Indo- Aryan Languages, Routledge, 250-285

Sogaard, Anders. 2005. Compounding Theories and Linguistic Diversity In Linguistic Diversity and Language Theories. John Banjamin Publishers Company.

Shah, Syed Mustafa. (2002). Urdu Nasal Consonant and Phonological Behaviour, Akhbar-eUrdu (Urdu Magazine), Muqtadra Qaumi Zaban Urdu Language Authority, Islamabad Pakistan, April-May Edition

Shahid, Syed Raza. 2002. A Study on Stop in Urdu. Centre for Urdu Research, Pakistan

Thakur, Anil. Kumar. 1997. Genitive Construction in Hindi. M. Phil Dissertation Submitted to the University of Delhi

Versteegh, Kees. 2001. The Arabic Language Edinburgh: Edinburgh University Press

Waqar, Amna \& Waqar, Sahar. 2002. Identification of Diphthong in Urdu and their Accoustic Properties.

Watson, Janet. C. E. 2002. The Phonology and Morphology of Arabic. Oxford University Press.

Wegener, H. (2004). Pizzas und Pizzen - die Pluralformen (un)assimilierter Fremdwörterim Deutschen. Zeitschrift für Sprachwissenschaft 23, 47-112.

Winter, Froemel. Esme. 2008, Studying Loan Words and Loanword Integration: Two Criteria of Conformity. Newcastle W. Papers, Vol. 14: pp, 156-157, 159, 163

http://www.bbc.co.uk/languages/other/guide/urdu/history.shtml (Retrieved: 06/09/2010)

http://www.stars21.com/dictionary/English-Malay dictionary.html 